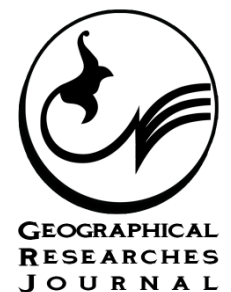

\title{
Analyzing and Investigating Effective Factors on Creating and Promoting Gully Erosions in Shorchay Watershed
}

\section{ART ICLE INF 0}

\section{Article Type}

Original Research

\section{Authors}

Besharati B. ${ }^{1} M A$

Abedini M.* $P h D$

Asghari S. ${ }^{2} P h D$
${ }^{1}$ Department of Geomorpholo-gy, Faculty of Literature and Humanities, Mohaghegh Ardabili University, Ardabil, Iran

*Department of Geomorphology, Faculty of Literature and Humanities, Mohaghegh Ar-dabili. University, Ardabil, Iran

${ }^{2}$ Department of Geomorphology, Faculty of Literature and Humanities, Mohaghegh Ardabili University, Ardabil, Iran

\section{*Correspondence}

Address: Department of Geomorphology, Faculty of Literature and Humanities, Mohaghegh Ardabili. University, Ardabil, Iran

Phone: -

Fax: -

Abedini@uma.ac.ir

\section{Article History}

Received: October 9, 2017

Accepted: July 17, 2018

ePublished: September 17, 2018

\section{A B S T RACT}

Introduction and Background Gully erosion is one of the most advanced kind of water erosion that carries a lot of sediment and causes various environmental challenges. Therefore, identifying and investigating of effective factors is necessary on forming and promoting of erosion in study area. Aims The aim of this study is to evaluate the factors influencing on dynam-ic of area Gullies in a one year time period.

Methodology In this study, electrical conductivity, sodium absorption ratio, PH, soil type and WS index has been used for analyzing of gully erosion po-tential.

Conclusion Results indicate that according to WS index the study basin has much potential for gully erosion as of gullies morphometry indicates much speed of promotion of gullies, laboratory results of sample soils of soluble minerals, SAR, electrical conductivity, the amount of sodium in soil are ef-fective on piping erosion are the most important effective factors on for-mation and promotion of gully erosion and morphometric characteristics of gullies. It is thought from the results of study that physical and chemical conditions of soil and rainfall have been effective on soil erosion and gullies development from length and width.

Keywords Gully Erosion; Morphometry; Physical and Chemical Characteristics of Soil; Shoorchay Basin

\section{I T A T I O N L I N KS}

[Abedini; 2009] Quantity study on hydrogeomorphological issues of Lykwan Chai river with emphasis on ...; [Abedini; 2013] Quantitative analysis of gully erosion in Kalghan-Chaj basin ...; [Ahmadi; 1999] Applied geomorphology ...; [Asghari Saraskanroud; 2017] Analysis of affecting factors on creating gully in the eastern shores of ...; [Bayati Khatibi, et al; 2011] Study of topographic thresholds and analysis of the role of type of surface formation in the development of gullies in the mountains of semi-aride ...; [Conoscenti et al.; 2014] Gully erosion susceptibility assessment by means of GIS-based logistic regression ...; [Danladi \& Ray; 2014] An analysis of some soil properties along gully erosion sites under different land use areas of Gombe ...; [Deng, et al; 2015] Planar morphology and controlling factors of the gullies in the Yuanmou ...; [Ehiz \& Omougbo; 2013] Evaluating factors responsible for gully development at the University ...; [Feizenya, et al; 2007] The study of the gully erosion of the Aghajari marlian formation in ...; [Ghodousi \& Davari-Rad; 2012] The Effect of physical and chemical properties of soil in gully erosion evente ...; [Ismail-Nejad, et al; 2012] The effect of physical, chemical and soil physiogical properties on the ...; [Jahanatigh \& Tabeh; 2017] Comparing soil physico-chemical characteristics and trapezoidal and v-shaped gully ...; [Kardel \& Tajari; 2015] Influence of gully erosion on soil moisture of abandoned farming dry land and rangeland in ...; [Khoojeh, et al; 2012] Investigation of the relation of soil physiochemical characteristics and initiation and expansion of gully erosion in Temer ...; [Mallam, et al; 2016] An assessment of gully erosion in kano ...; [Mohammad Ebrahimi \& Vafakhah; 2015] Investigation of the role of soil and non-soil parameters in development of linear gully erosion in Agh ...; [Nohehgar \& Heidarzadeh; 2011] Study of physico-chemical and morphometric properties of gully ...; [Oparaku \& Iwar; 2018] Relationships between average gully depths and widths on geological sediments underlying the Idah-Ankpa Plateau of the North ...; [Oyegun, et al; 2016] Gully characterization and soil properties in selected communities in Ideato South ...; [Poesen et al.; 2002] Gully Erosion in ...; [Refahi; 2009] Water erosion and its control ...; [Rienks, et al; 2000] Some physical and chemical properties of sediments exposed in a ...; [Servati, et al; 2008] Effective factors in the formation and expansion of ...; [Shadfar; 2010] Introduction to gully erosion ...; [Shahrivar, et al; 2012] Roles of SAR and EC in gully ...; [Shit, et al; 2013] Assessment of factors affecting ephemeral gully development ...; [Tebebu et al.; 2010] Surface and subsurface flow effect on permanent gully formation and upland erosion ...; [Valentin, et al; 2005] Gully erosion: Impacts, factors and ...; [Yousefwand, et al; 2013] Lithological and geological impacts on gully erosion ... 
Beasharati B. MA

Abedini M. PhD

Asghari S. PhD

Abedini@uma.ac.ir
بشير بشارتى، دانشجوى دكترى، گروه جغرافيا طبيعى، دانشكده ادبيات و علوم انسانى، دانشگاه محقت اردبيلى، اردبيل، ايران د كتر موسى عابدينى، دانشيار، گروه جغرافيا طبيعى، دانشكده ادبيات و علوم انسانى، دانشكاه محقق اردبيلى، اردبيل، ايران دكتر صياد اصغرى، دانشيار، كروه جغرافيا طبيعى، دانشكده ادبيات و علوم انسانى، دانشگاه محقق اردبيلى، اردبيل،ايران

\title{
بررسى و تجزيلوتحليل عوامل موثر بر ايجاد و توسعه فرساي خندقى در حوضه آبخيز شور خاى
}

\author{
ونذيرش نهايى:TV/F \\ دريافت مقاله:9ع/VIV
}

DOI: $10.29252 /$ geores.33.2.206

جكيده

مقدمه: فرسايش خندقى يكى از ييشرفته ترين نوع فرسايش آبى است كه مقدار زيادى رسوب را با خود حمل مى كند و باعث ايجاد خالشهاى مختلف زيست محيطى مى شود هدف: اين تحقيق ارزيابى ميزان رشد و عوامل مؤثر در ايجاد خندقهاى مندئس منطقه در بازه زمانى يكساله مىباشد.

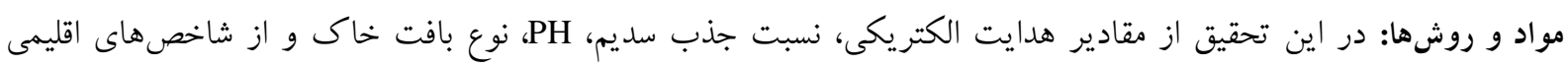
براى تحليل استعداد خندقزايى منطقه استفاده شده است.

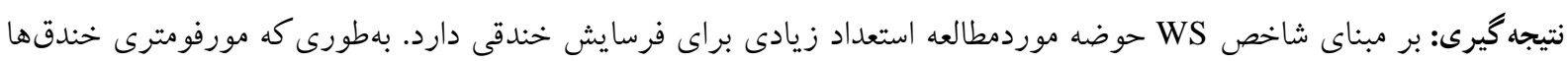

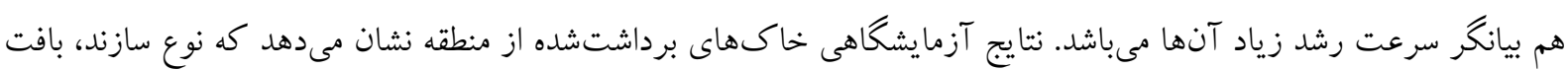

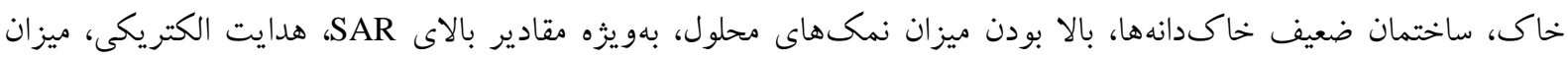

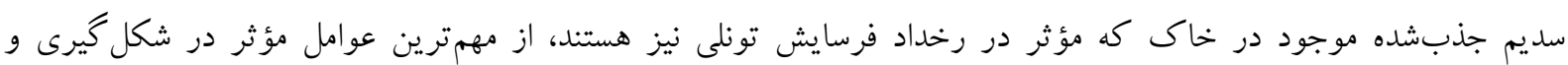

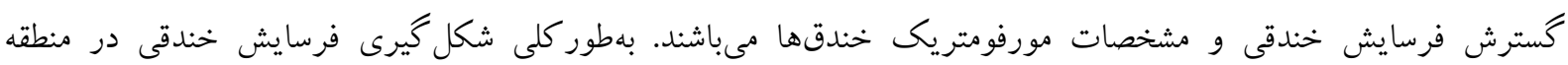

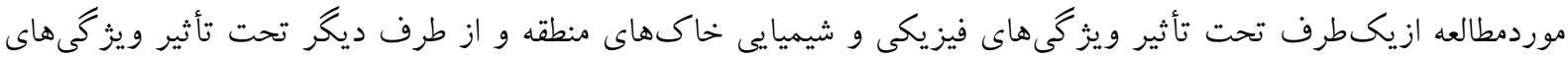
اقليمى قرار دارد.

وازگان كليدى: فرسايش خندقى، مورفومترى، ويزگىهاى فيزيكى و شيميايى خاك، حوضه شورجاى

مقدمه

فرسايش آبى با اشكال مختلفى بر روى زمين ظاهر مىشود كه يكى از يِيشرفتهترين آن فرسايش خندقى مىباشد و از عوامل

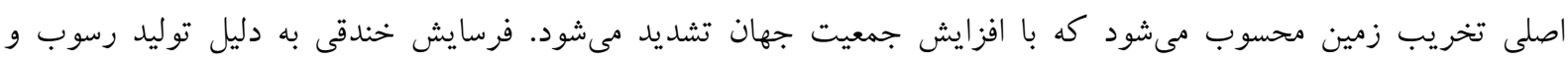

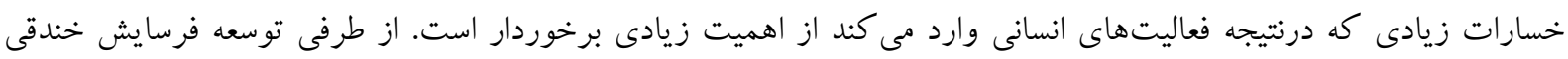

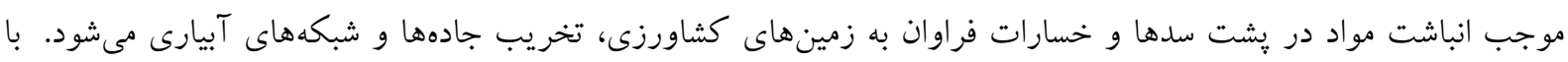
توجه به اينكه بخش زيادى از تلفات خاكى مربوط به اين نوع فرسايش است و نقش بازدارندهاى در توسعه و ويشرفت

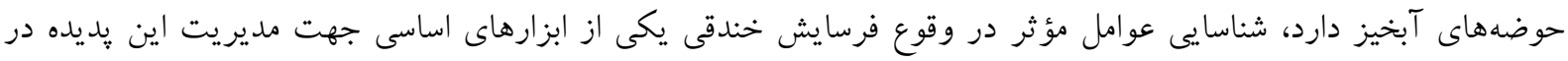




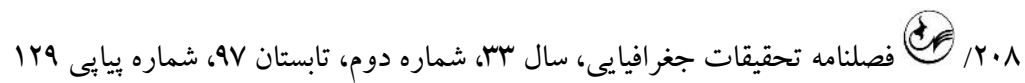
منطقه موردمطالعه مىباشد. خندق، آبراههاى است نسبتاً دائمى كه جريانهاى موقت آب در هنگام بارندگى از آن مى گذرد و

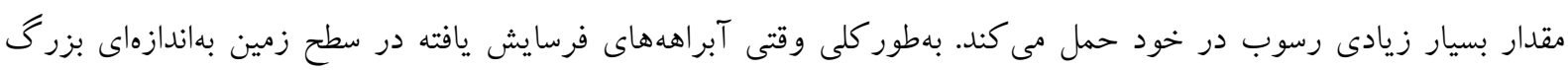

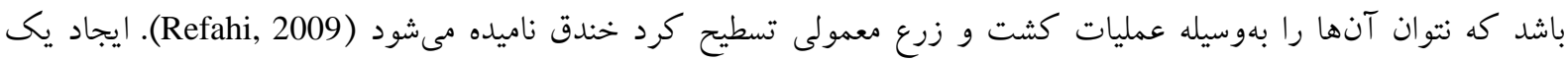

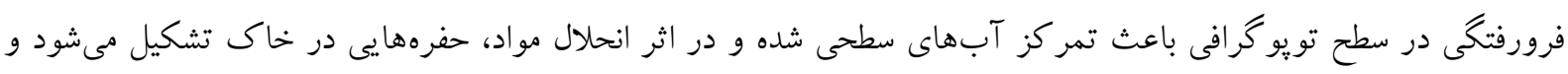
با توسعه كانال و ريزش سقف بريدگى عمودى تشكيل مى گردد (Feizenya, Heshmati, Ahmadi, \& Ghodousi, 2007).

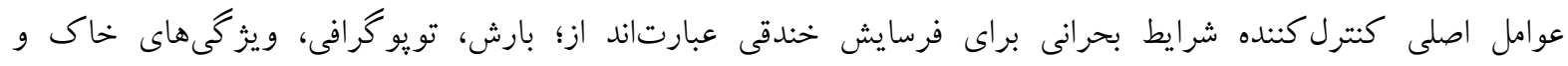

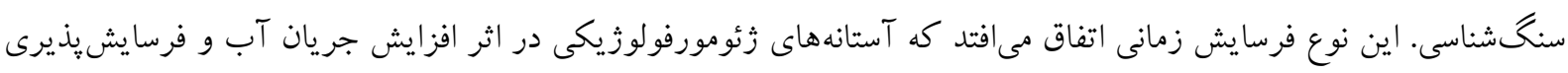

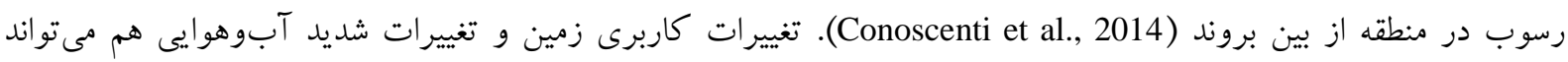

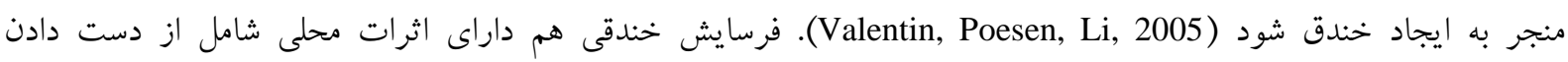

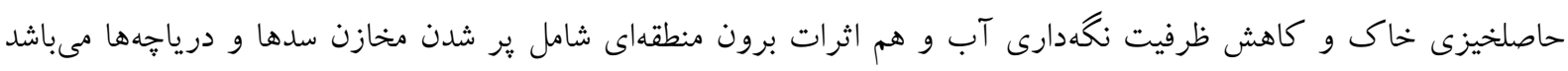
(Tebebu et al., 2010)

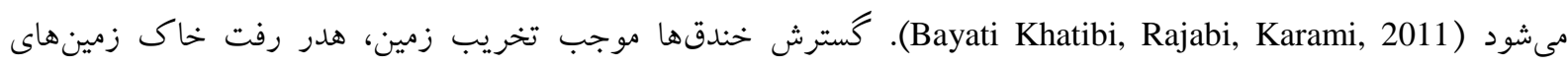

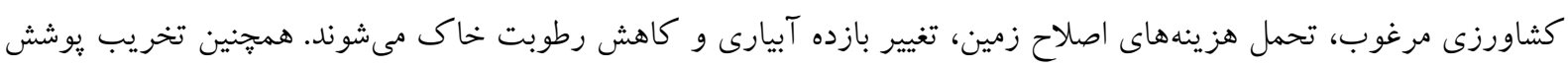

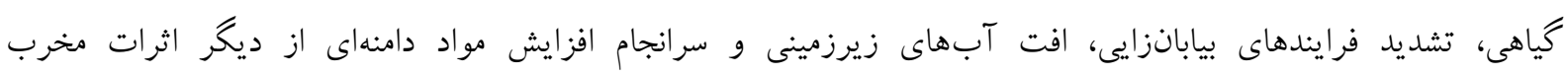

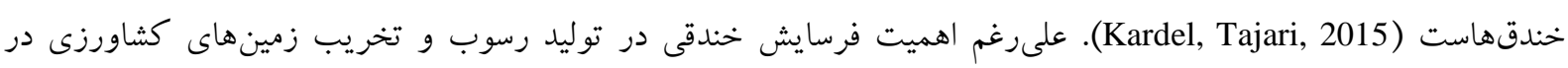

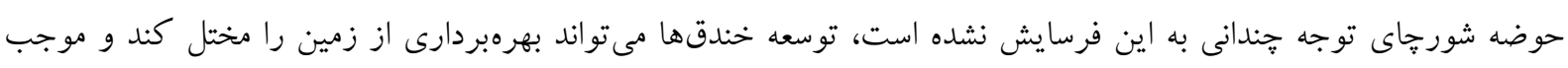

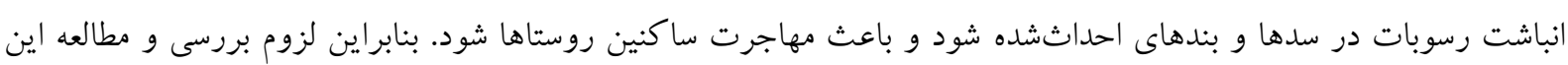

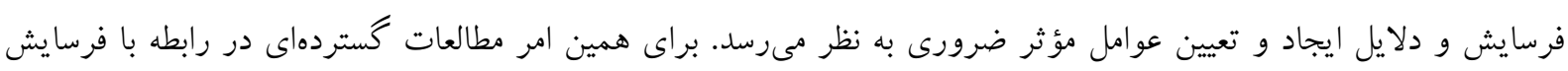
خندقى در خارج و داخل كشور انجام گرفته است.

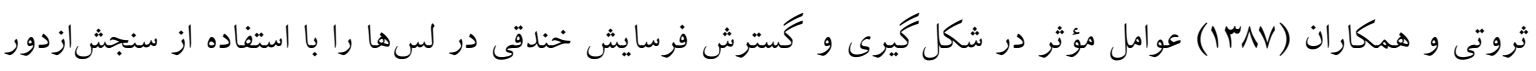

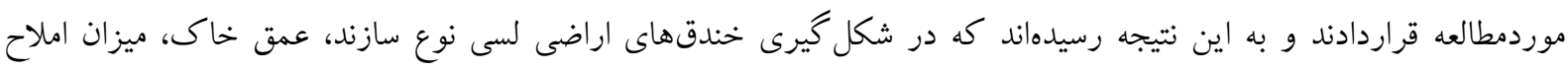
محلول، SAR، هدايت الكتريكى و ميزان سديم قابل تبادل بيشترين تأثير رادارند (Servati, Ghodousi, \& Dadkhah, 2008).

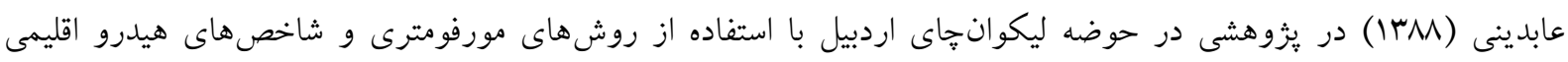

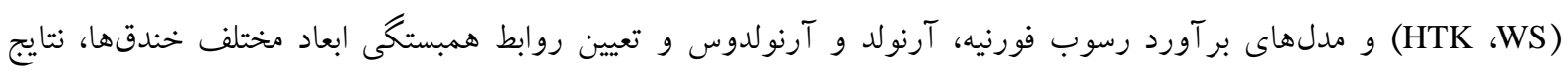

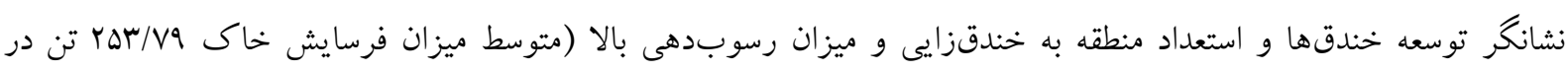

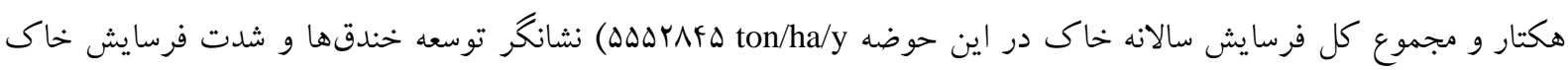

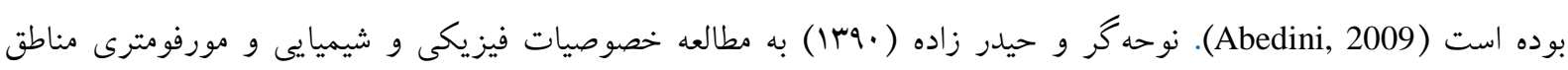

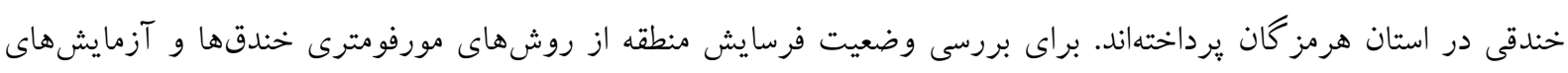

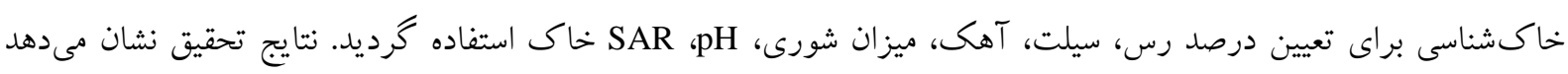
كه افزايش درصد سيلت و رس زمينهساز فرسايش خندقى بوده است (Nohehgar \& Heidarzadeh, 2011). اسماعيل نزاد و

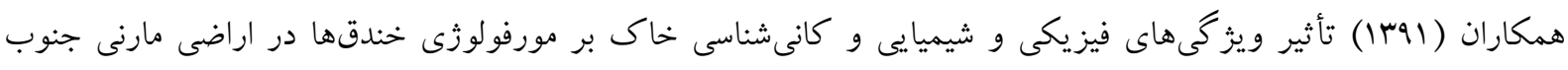

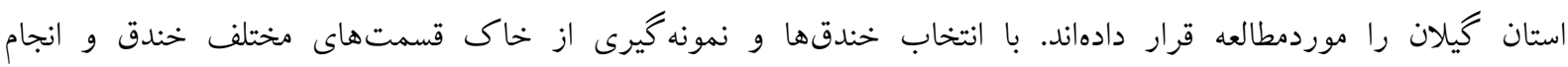

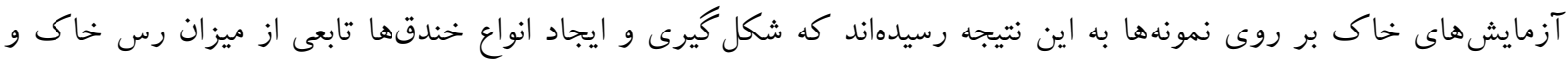


نوع رس و ميزان سديم محلول تبادلى بوده است (Ismail-Nejad, Sayed-Mohammadi, \& Bakhshipour, 2012). خوجه و همكاران (اله||) ارتباط خصوصيات فيزيكى و شيميايى خاك در كسترش فرسايش خندقى در استان كلستان را بررسى كردند. جهت تعيين خصوصيات فيزيكى و شيميايى خاك اقدام به نمونهبردارى خاك خندقها كرديده است و ارتباط ويز گیىهاى خاكى و رشد خندقها را با استفاده از مدل ركرسيونى ارائه كردهاند. نتايج تحقيق نقش مؤثر خصوصيات فيزيكى و شيميايى خاك بهويزه ميزان سيلت، املاح محلول و درجه اشباع خاك در شكل كيرى و كسترش فرسايش خندقى در سازند لسى را نشان مى هد (Khoojeh, Ghodousi, \& Esmaeili, 2012). عابدينى (rarr) با استفاده از روش هاى مورفومترى و شاخص هاى هيدرو اقليمى و روابط رگرسيونى درباره خندقزايى در حوضه كلقانجاى در دامنه سهند كاركرده و نتايج نشان مىدهد كه خندقزايى در منطقه بالا و متوسط ميزان فرسايش خاك اهله//91 تن در هكتار و مجموع كل فرسايش سالانه خاك در اين حوضه Abedini, ) بـ MFFFrV· ton/ha/y 2013). محمدابراهيمى و همكاران (IFF) به بررسى ارتباط عوامل مؤثر خاكى و غيرخاكى در ايجاد فرسايش خندقى خطى حوضه آق امام در استان كلستان يرداختهاند. در اين تحقيق از طريق آزمون مقايسه ميانكين نمونه به روش كرفتهاند كه از بين خصوصيات خاك درصد رس (سطحى و زيرسطحى)، درصد سيلت، درصد رطوبت اشباع، كربن آلى و آهى سطحى و زيرسطحى و از بين فاكتورهاى غيرخاكى ليتولوزى سازند لسى در ايجاد فرسايش خندقى منطقه نقش مؤثرى دارند (Mohammad Ebrahimi \& Vafakhah, 2015). اصغرى(عهاן) به تحليل عوامل مؤثر بر خندقزايى در حاشيه شرقى سواحل درياجه اروميه با استفاده از روشهاى مورفومترى و آزمايشگاهى به اين نتيجه رسيده است كه شكل گيرى فرسايش

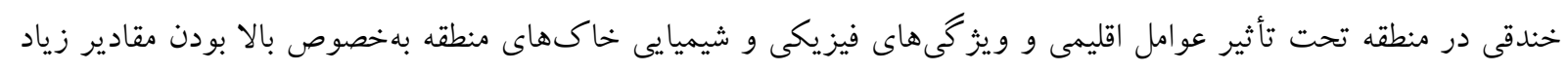
(SAR EC) خندقى در دانشخاه بنين در ايالت نيجريه يرداختهاند. در اين تحقيق با استفاده از روشهاى آزمايشخاهى نمونهاى خاكى، به

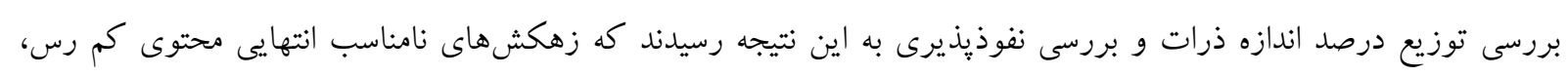

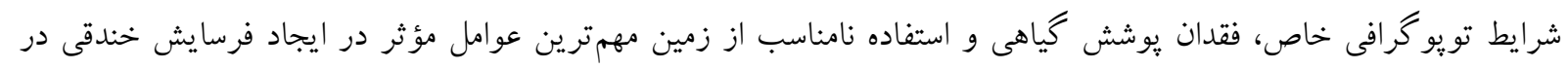

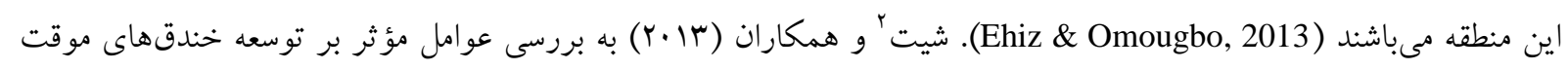
در زمينهاى بدلند در هندوستان يرداختهاند. يس از انتخاب دوازده خندق بهطور تصادفى با استفاده از روشهاى مورفومترى ابعاد مختلف خندقها را در فصل هاى مختلف جهت رشد هندسى آنها و هدر رفت خاكى اندازه گيرى نمودند. نتايج تحقيق نشان داد Shit, Bhunia, \& Maiti, ) ارتباط شديدى بين متغيرهاى شدت بارش، حجم روان آب و شيب دامنه با توسعه خندقها وجود دارد

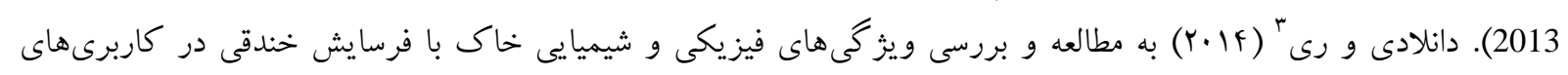
مختلف در كلانشهر كامبى در نيجريه با استفاده از تحليل واريانس آنوا به اين نتيجه رسيدهاند كه بالا بودن مقدار شن و يايين بودن سيلت و رس در نمونه هاى خاك برداشتشده از عمقهاى مختلف در كاربرىهاى متفاوت موجب از هم زياشيدن خاكى به خاطر نابيوستى ذرات در مقابل سيلابهاى شديد شده و زمينه را براى گسترش عرضى و عمقى خندقها فراهم نموده است

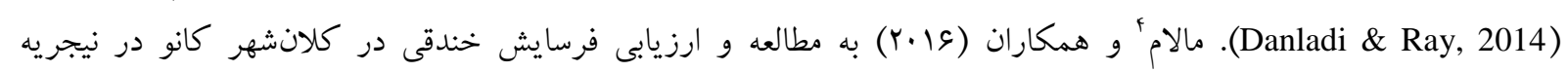
يرداختهاند و با استفاده از روشهاى آزمايشخاهى نمونهاى برداشتشده و مورفومترى خندقها به اين نتيجه رسيدهاند كه

1 Ehiz and Omougbo 


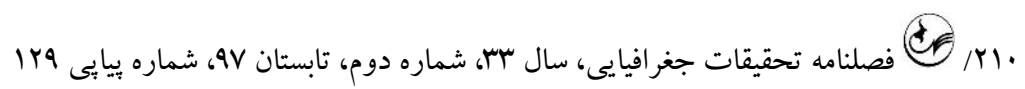
كيفيت خاك در منطقه شرايط مساعدى را براى گسترش و يِيشروى عمق، طول و عرض خندقها فراهم نموده است و ميزان كسترش خندقها از ناحيه هد كت بهطور متوسط ب تا V Vتر مى مباشد (Mallam, Iguisi, \& Tasiu, 2016).

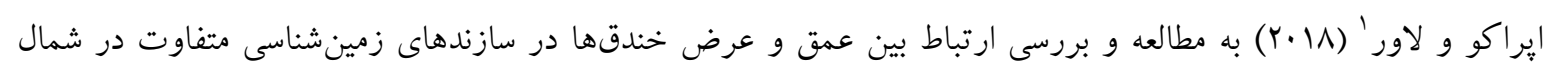

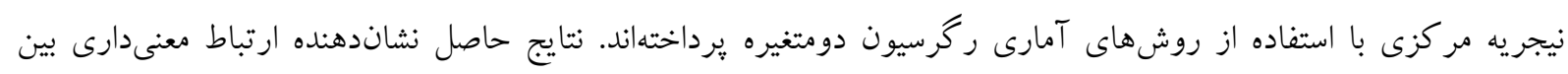

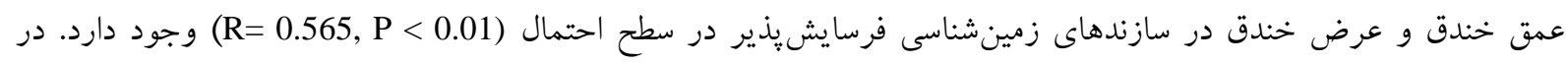

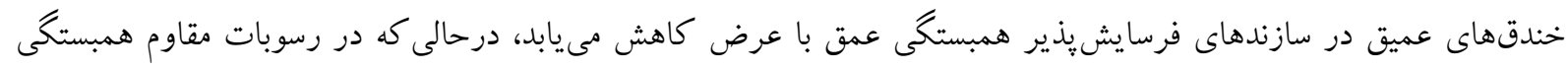
عمق با عرض خندق افزايش مىيابد (Oparaku \& Iwar, 2018).

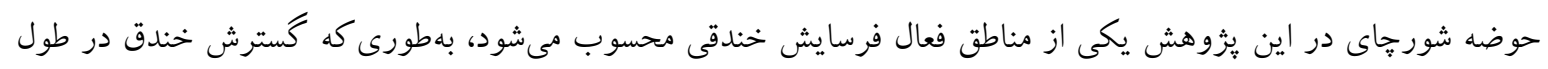

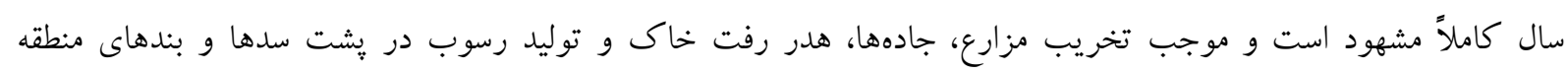

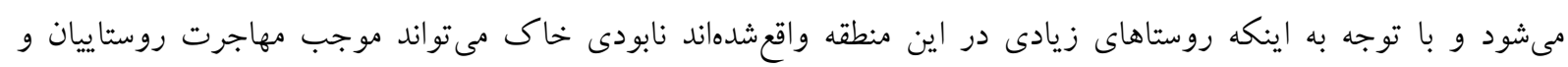

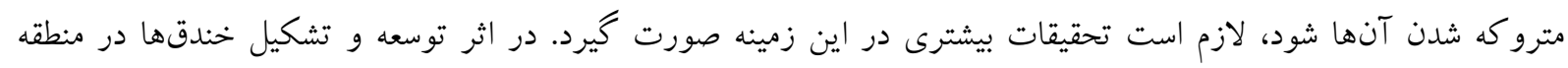

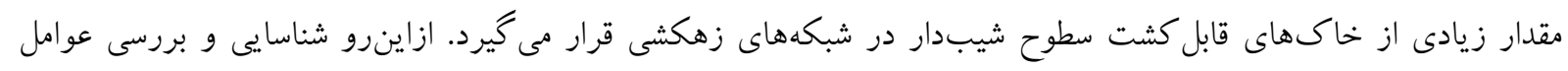

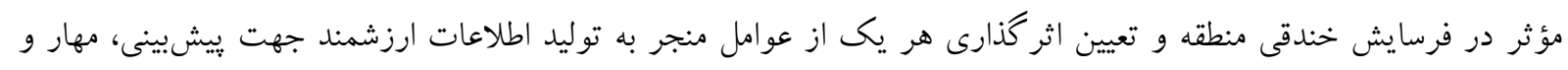

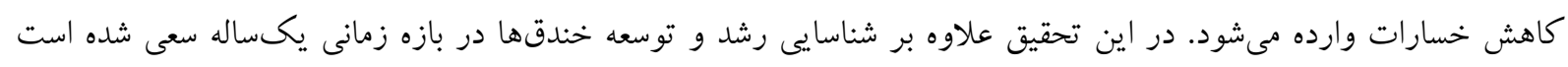

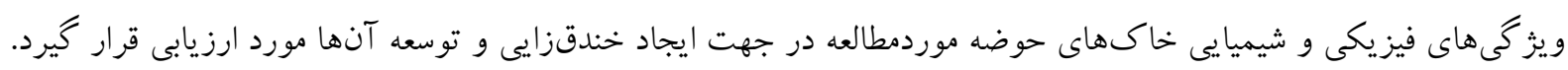

منطقه موردمطالعه

حوضه شورجاى از زير حوضههاى مهم حوضه بزرگ قرانقوجاى محسوب مىشود كه در دامنه هاى شرقى كوهستان سهند

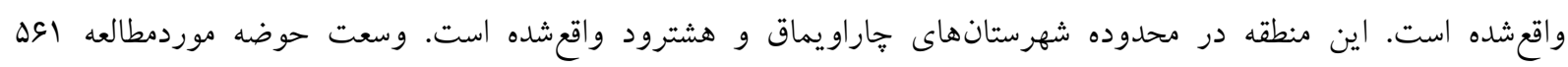

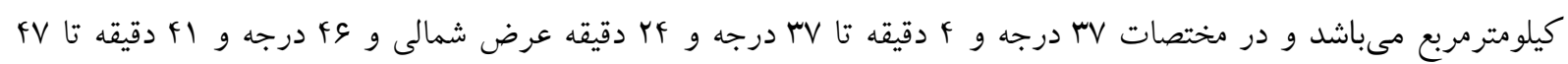

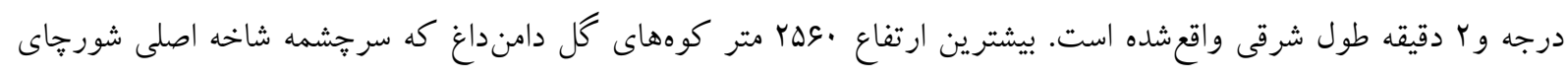

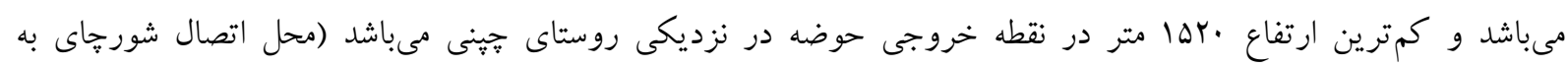

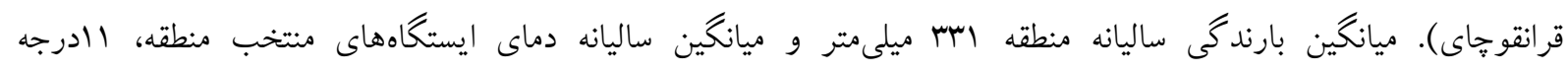

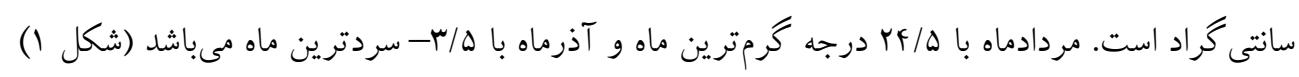




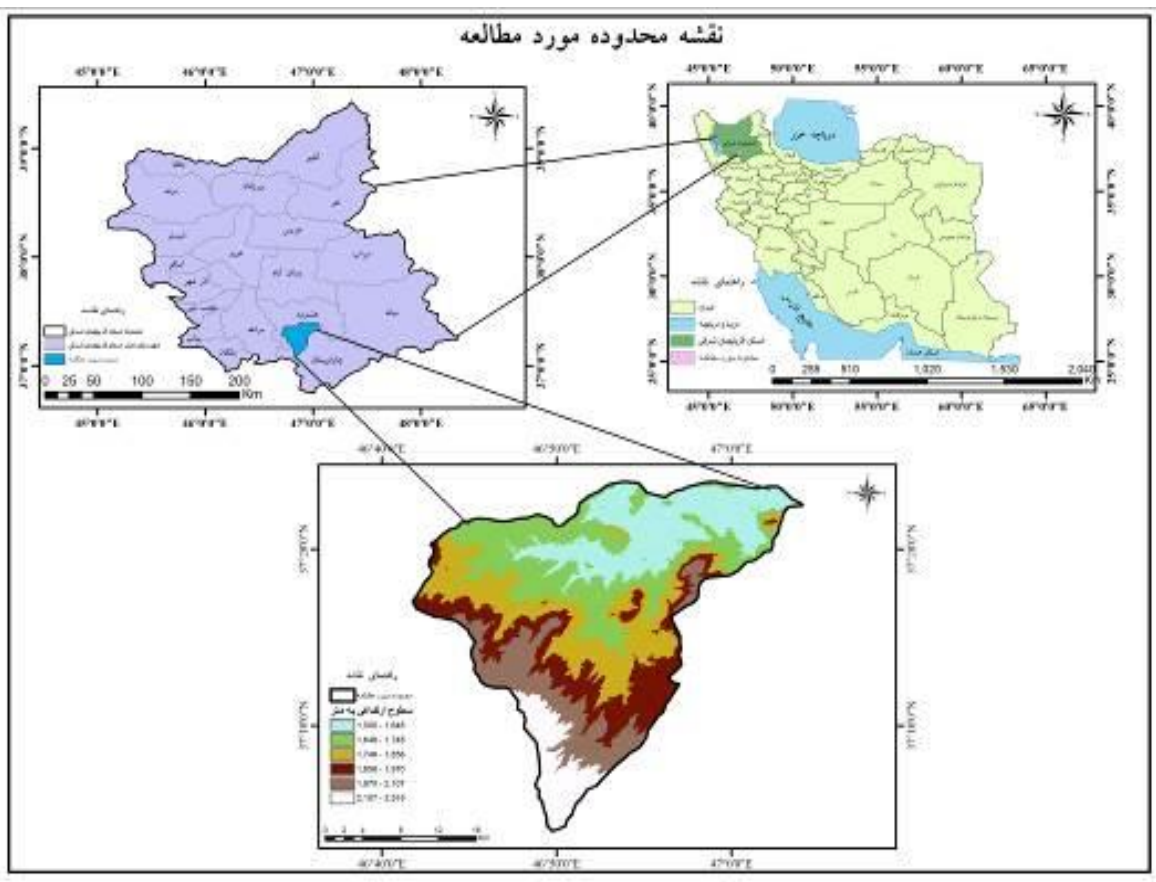

شكل ا - موقعيت جغرافيايى حوضه شورجاى

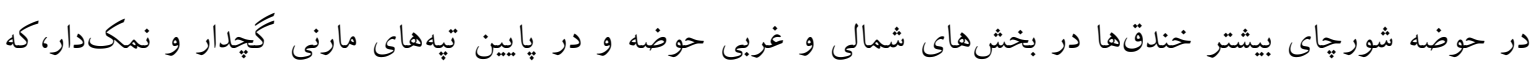

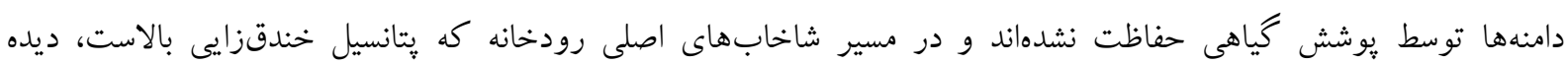

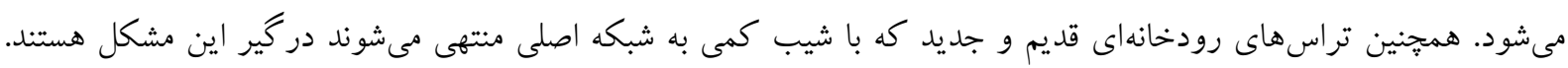

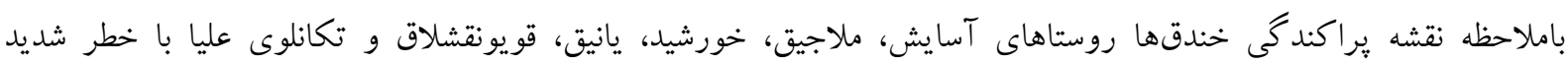

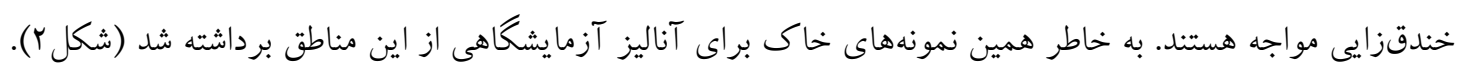

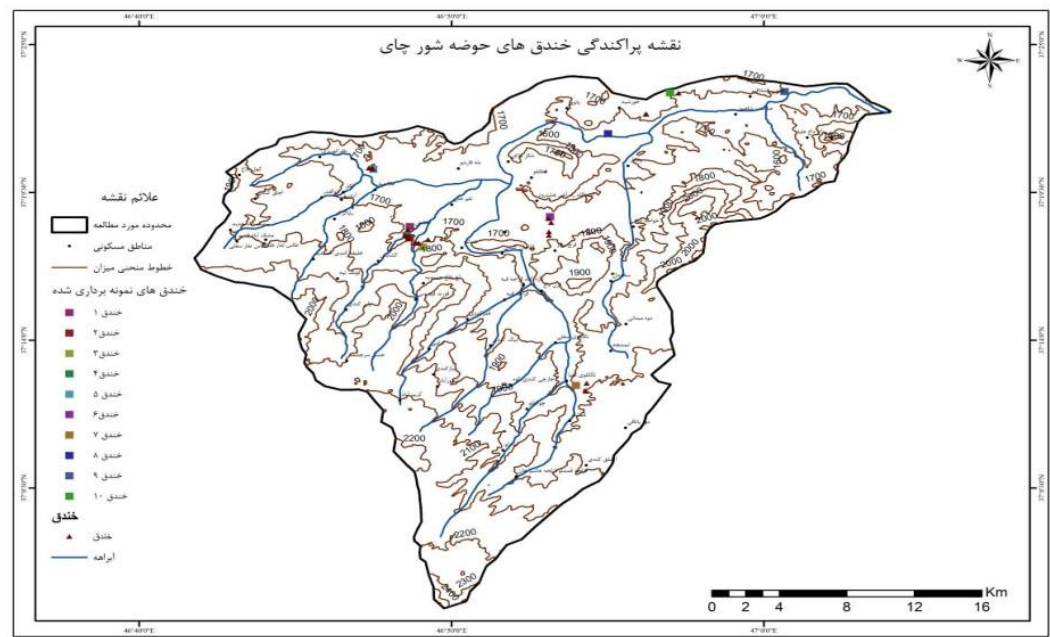

شكل r- نقشه يراكند

زمينشناسى منطقه موردمطالعه

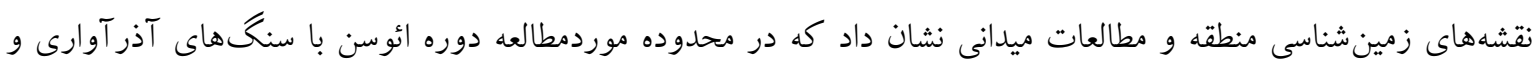

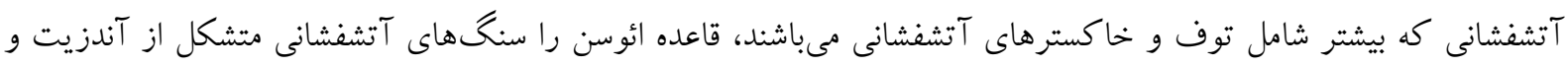

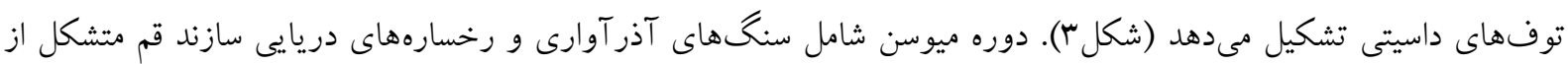




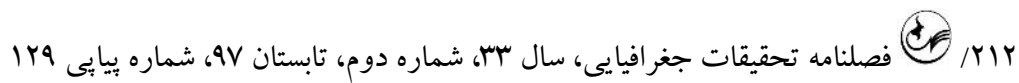
آهك ها مىباشد كه در بعضى جاها توسط رسوبات پاد كانهاى آبرفتى يوشيده شدهاند. رسوبات تبخيرى و تخريبى دوره ميوسن

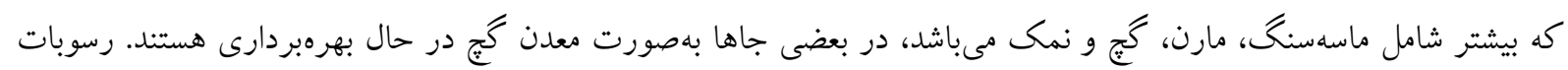

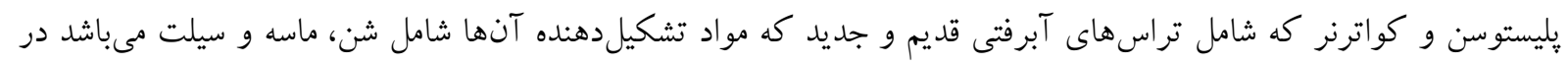

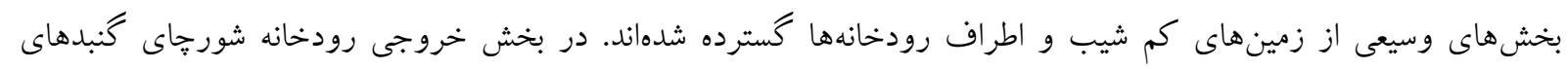

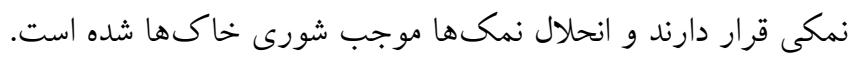

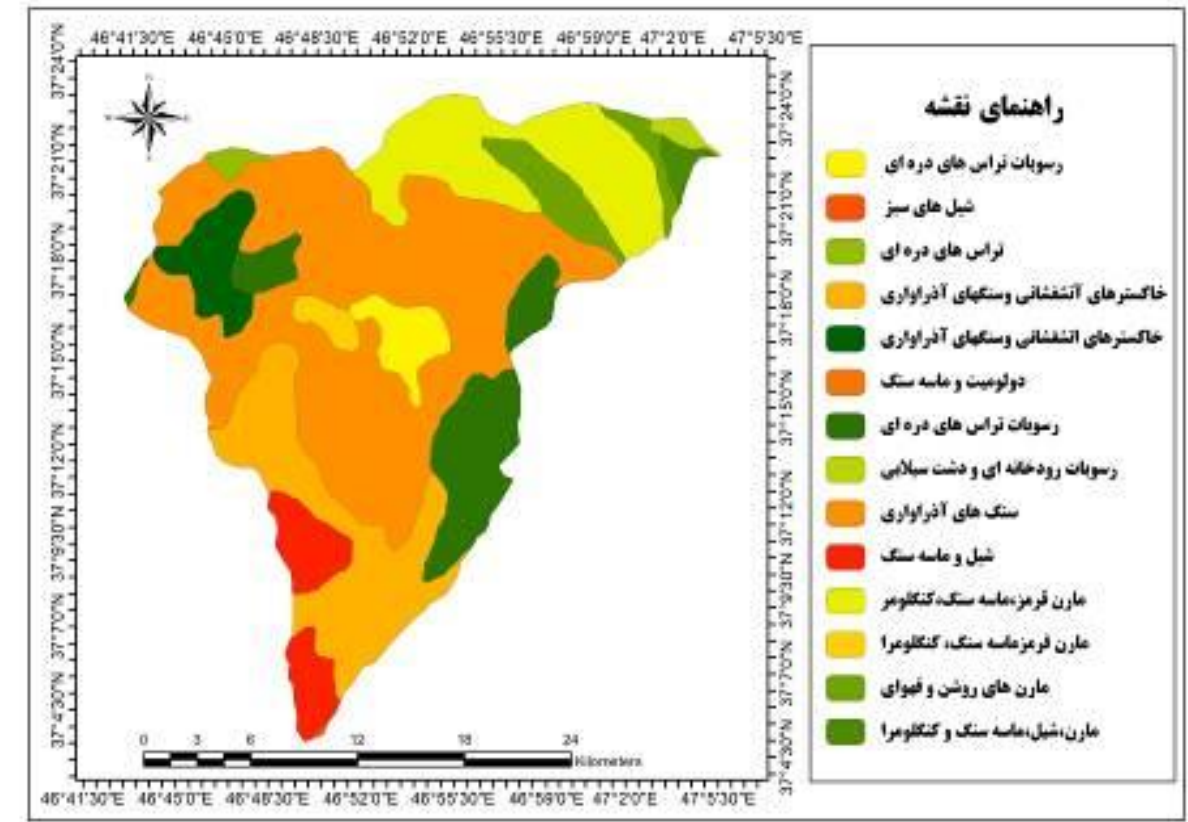

\section{شكل r- نقشه زمينشناسى حوضه شورجاى}

مواد و روشها

روش تحقيق در اين مطالعه بيشتر بهصورت كتابخانهاى، مطالعات ميدانى، اندازهيرىهاى مورفومترى، آزمايشكاهى و استفاده از مدلهاى تجربى به شرح زير بوده است:

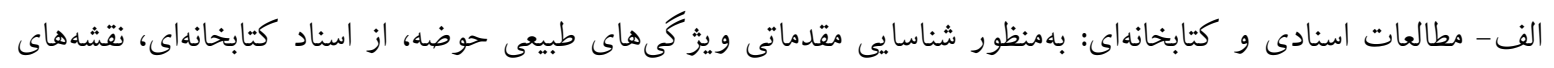

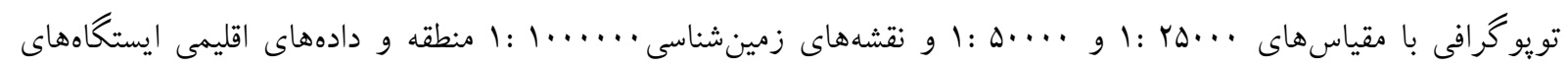
هشترود، جاراويماق و نظر كهريزى، تصاوير گو گل ارث استفاده شده است.

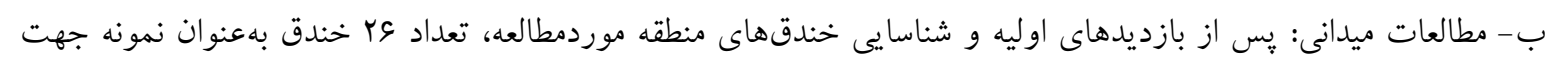

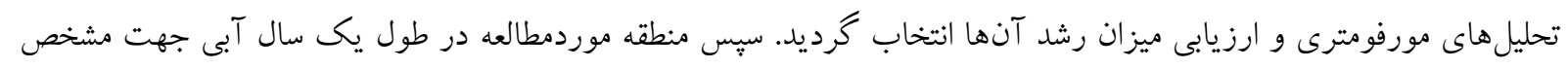

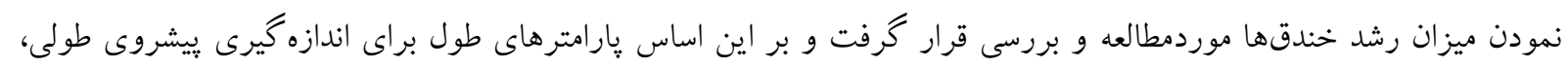

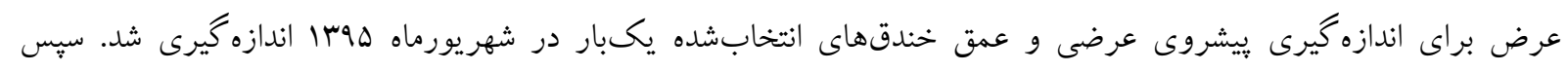

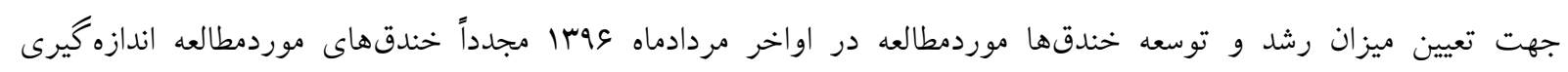

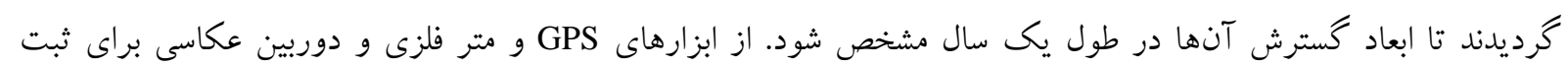
موقعيت و مشخصات خندقها استفاده كرديد. 
بررسى و تجزيه و تحليل عوامل موثر بر ايجاد و توسعه فرسايش خندقى ... / بال

ج- مطالعات آزمايشكاهى: جهت بررسىهاى فيزيكى و شيميايى خاكهاى منطقه و تجزيهوتحليلهاى آزمايشگاهى تعداد

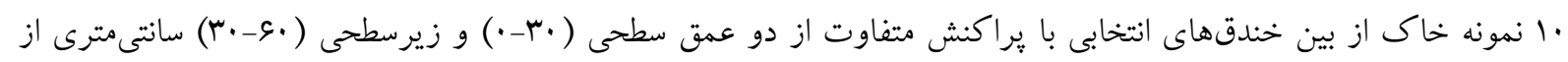
ديواره خندقها برداشته شد و دركيسههاى نايلونى جمع آورى گرديد. نمونهاى خاك يس از عبو عبور از الكى دو ميلىمترى، به آزمايشخاه خاك دانشكده كشاورزى دانشخاه محقق اردبيلى منتقل شدند و مورد آناليز آزمايشخاهى قرار كرفتند. خصوصيات فيزيكى (درصد رس، درصد سيلت، درصد شن) به روش هيدرومترى و خصوصيات شيميايى (درصد رطوبت اشباع، هدايت الكتريكى، درصد ماده آلى، درصد سديم تبادلى، نسبت جذب سديم) براى نمونههاى موردنظر اندازه گيرى شد. نسبت جذب سديم (SAR) بر اساس نسبت بين كاتيونهاى كلسيم و منيزيم با سديم و واكنش خاكى نيز با pH اندازه كيرى شد. نسبت جذب دأب سديم با استفاده از رابطه ا محاسبه كرديد(Asghari Saraskanroud, 2017).

$\mathrm{SAR}=[\mathrm{Na}+] /(([\mathrm{Ca} 2+]+[\mathrm{Mg} 2+]) / 2) 1 / 2$

رابطه (1)

مقادير EC و SAR براى طبقهبندى خاكهاى متأثر از نمك استفاده مىشود. واسكوم' و همكاران به نقل از شهريور و Shahrivar, Boon Sung, Jessop, Rahim, \& ( همكاران (r إr) خاك ها را بر اساس جدول ا به سه گروه طبقهبندى كردند

.(Sufi, 2012

جدول ا - طبقلبندى خاككها بر اساس مقادير EC و SAR

\begin{tabular}{|c|c|c|c|}
\hline SAR & $\mathrm{pH}$ & $\mathrm{EC}(\mathrm{ds} / \mathrm{m})$ & \\
\hline$<1 r$ & $<\Lambda / \Delta$ & $>f$ & شور \\
\hline$\geq 1 r$ & $>\Lambda / \Delta$ & $<F$ & سديمى \\
\hline$\geq 1 \pi$ & $<\Lambda / \Delta$ & $>f$ & شور سديمى \\
\hline
\end{tabular}

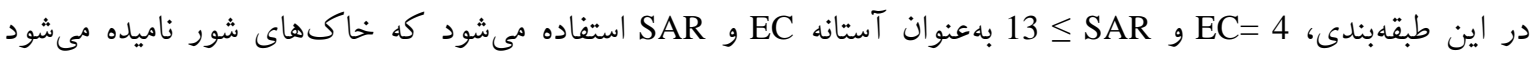

.(Asghari Saraskanroud, 2017)

د- استفاده از مدلهاى تجربى: بعد از نمونهبردارى و انجام آزمايشهاى لازم كه در بالا ذكر شد و نيز جمع آورى دادههاى اقليمى لازم با استفاده از مدلهاى تجربى مختلف اقدام به بررسى و تجزيهو تحليل نتايج حاصل از آنها شد.

ضريب رطوبت در سازندهاى منطقه

شاخصى كه با استفاده از آن مىتوان گتانسيل خندقزايى منطقه را با يارامترهاى اقليمى در ارتباط كذاشت، ضريب مقدار

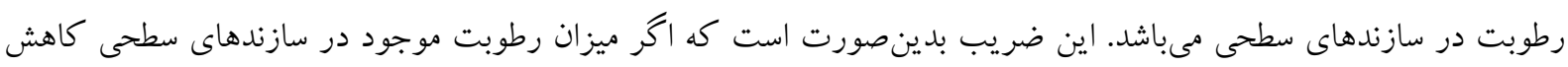
يابد به مفهوم كاهش رطوبت قابلجذب ريشه گياهان مىباشد و گياهان نمىتوانند از مقدار رطوبت ناجيز گّسبيده به ذرات

$\mathrm{Ws}=\mathrm{R}-\mathrm{RP} / \mathrm{t}$

خاك استفاده كنند و يزمرده مىشوند. ضريب Ws از رابطه زير محاسبه مى شود:

كه در اين رابطه Ws = شاخص رطوبت موجود در خاك، t = درجه حرارت ماهيانه، R= متوسط بارش ماهيانه به ميلى متر، RP ضريب مربوط به دما و از رابطه زير به دست مى آيد (Abedini, 2013).

$\mathrm{Rp}=30(\mathrm{t}+7)$ 


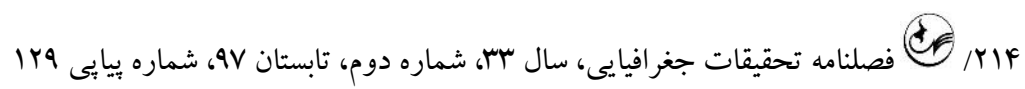

يافتهها

تجزيهو تحليل ميزان رطوبت مو جود در سازندها و نوسان آن در ييدايش خندقها

ميزان رطوبت و تغيير آن درنتيجه تناوب فصول خشك و مرطوب عامل مهم در به وجود آمدن تركىها و شيارها در

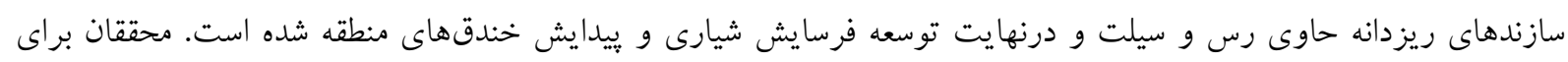

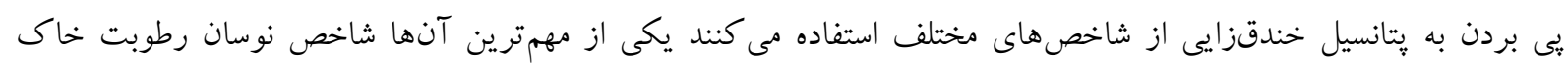

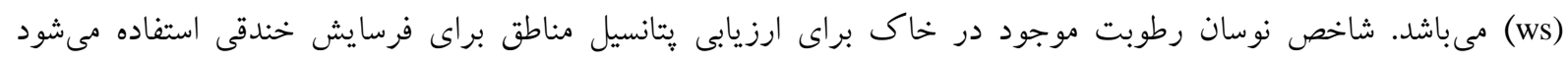

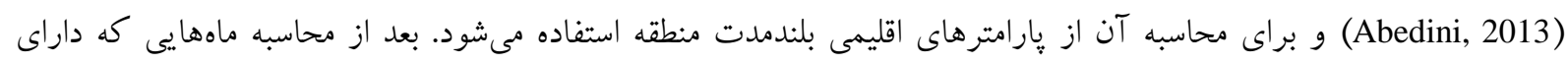

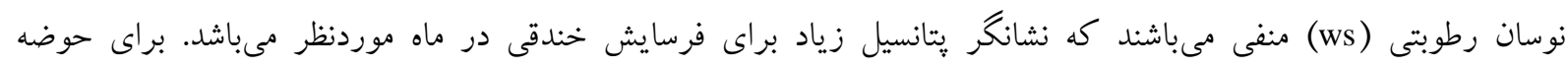

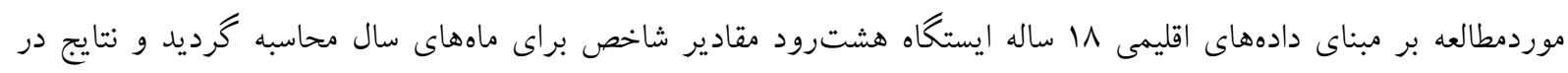

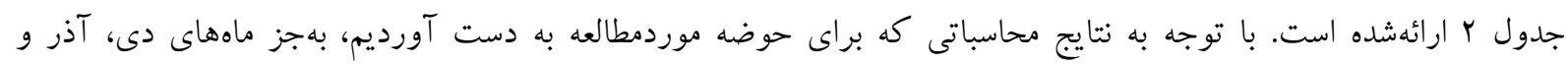

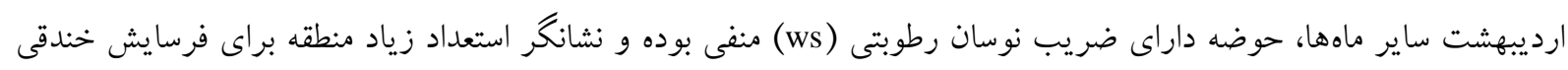

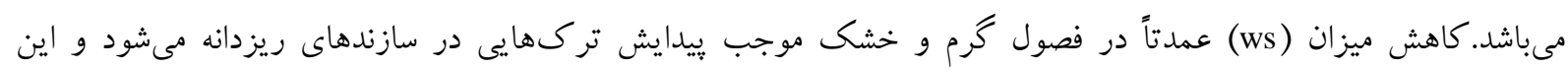

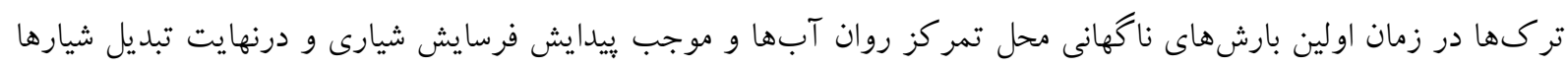

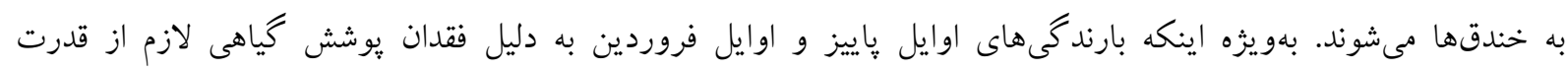
خندقزايى بالاترى برخوردارند.

جدول r- نتايج شاخص ws براى ماههاى سال در حوضه شورجاى

\begin{tabular}{|c|c|c|c|c|}
\hline WS & $\mathrm{RP}$ & $\mathrm{P}$ & $\mathrm{T}$ & ماه \\
\hline $1 \Delta N / r$ & 195 & $r \mu / 1$ & -18 & دى \\
\hline$-11 r / f$ & TEF & $r / s$ & $1 / \Lambda$ & بهمن \\
\hline$-r \Delta / \varepsilon$ & $\mu_{F \Lambda}$ & f. & $F / s$ & |سفند \\
\hline$-10 / 1$ & DIS & $s \Delta / V$ & $1 \cdot / r$ & فروردين \\
\hline$s / r$ & sVr & $F 9 / 1$ & $10 / f$ & ارديبهشت \\
\hline$-r \Lambda$ & $\Delta \mu_{F}$ & ir & $r \cdot / \Lambda$ & خرداد \\
\hline$-\mu r / V F$ & $9 F \Delta$ & $s / 1$ & $r F / D$ & تير \\
\hline$-\mu_{F} / \Lambda V$ & $q F \Delta$ & $r / V$ & $r F / D$ & مرداد \\
\hline$-r F / I V$ & WF & v & $N / \Lambda$ & شهريور \\
\hline$-r \Delta / \Lambda$ & $\Delta \Delta \Lambda$ & $r r / r$ & $11 / 8$ & مهر \\
\hline$-\Delta I / q F$ & TrV & $r 1 / q$ & $r / q$ & آبان \\
\hline$f / 9$ & $1 \cdot 0$ & $r \Delta / 1$ & $r / \Delta$ & آذر \\
\hline
\end{tabular}

براى بررسى وضعيت خاكى منطقه نمونههايى از خاكهاى موجود جمع آورى و آزمايشهايى روى آنها انجام شد كه نتايج

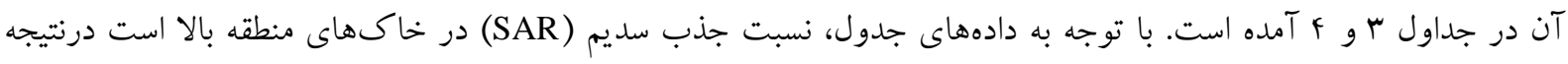

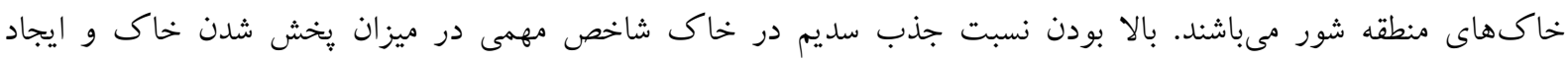

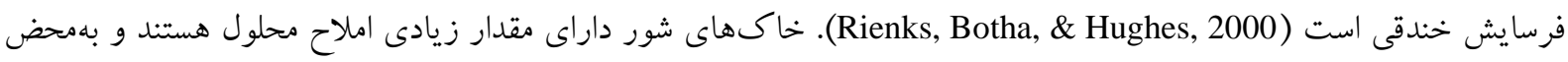


دريافت رطوبت ساختمان خاك متلاشى مىشود. افزايش نمكى در يروفيل خاك باعث افزايش غلظت محلول شده و يايدارى خاكىدانها با افزايش نسبت جذب سديم تنزل يافته درنتيجه فرسايش خاك تشديد مىشود. نسبت بالاى هدايت الكتريكى نيز نشانكر افزايش مواد قابل انحلال در منطقه مىباشد كه در مناطق كم شيب تجمع اين املاح مكانهاى مستعدى را براى رخداد فرسايش تونلى فراهم مى آورد. تراكم يونهاى سديم و منيزيم نيز باعث افزايش شدت انقباض و توسعه بيشتر شكاف ها شده و باعث افزايش قدرت انحلال آبهاى زيرزمينى مىشود درنتيجه خاكىهايى كه يونهاى كلسيم و سديم بيشترى دارند تونلهايى با عمق زياد ايجاد مى كنند.

\begin{tabular}{|c|c|c|c|c|}
\hline SAR & $\mathrm{Na}(\mathrm{ppm})$ & $\mathrm{Mg}(\mathrm{ppm})$ & $\mathrm{Ca}(\mathrm{ppm})$ & نمونه \\
\hline $11 / V \wedge$ & $1 s / V$. & $d r$ & 11 & 1 \\
\hline$\varepsilon$ & $F \cdot / V r$ & VF & 11 & r \\
\hline q/Ar & $\Delta \cdot / 1$. & ra & MF & $r$ \\
\hline$\Lambda / I V$ & $\Delta 1 / 8 \Lambda$ & Fr & щ & f \\
\hline $9 / 0$ & SN/Yr & sद & rv & $\Delta$ \\
\hline $1 \cdot / r \pi$ & $s \cdot / 0$. & FE & TF & $\varepsilon$ \\
\hline$F / F H$ & | & $\Lambda r$ & m & V \\
\hline $10 / 9$ & $V V / r \Lambda$ & سץ & 10 & $\wedge$ \\
\hline $9 / F T$ & $\Delta \Delta / V F$ & FD & ra & 9 \\
\hline $11 / \mathrm{M}$ & SE/SV & $\Delta V$ & 19 & 1. \\
\hline
\end{tabular}

خواص فيزيكى خاك سطحى اثر مهمى برافزايش ميزان نفوذيذيرى آب در خاك و كاهش روان آب دارد و مىتواند بر

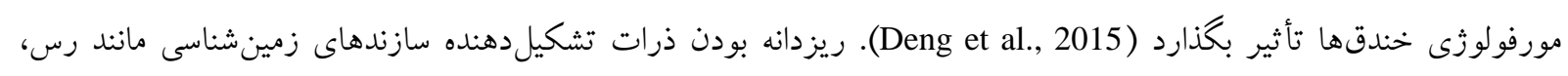

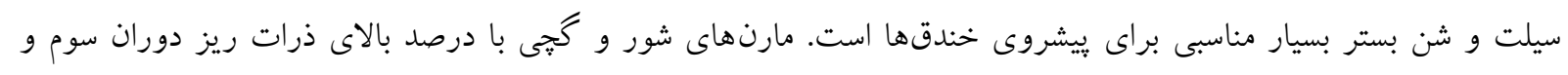

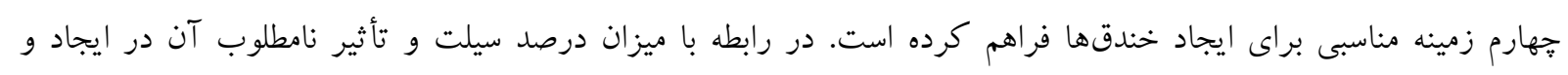

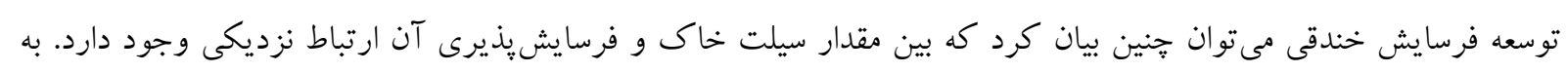

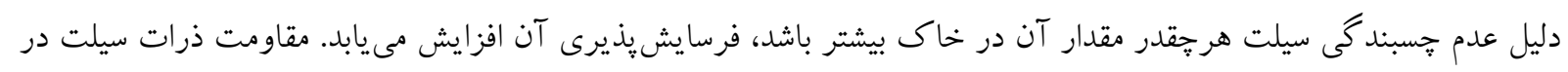

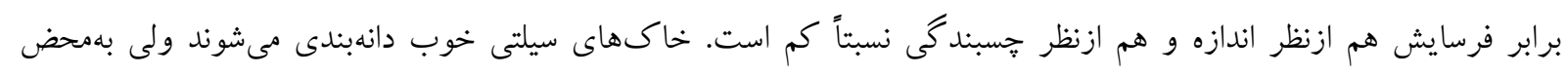

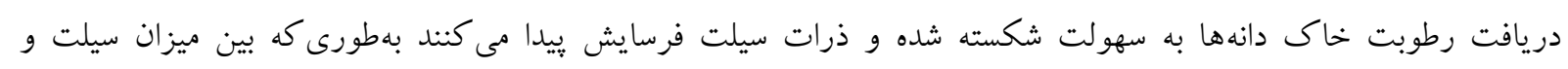

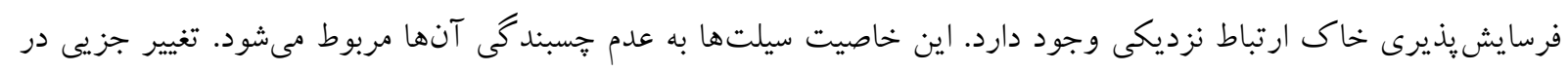

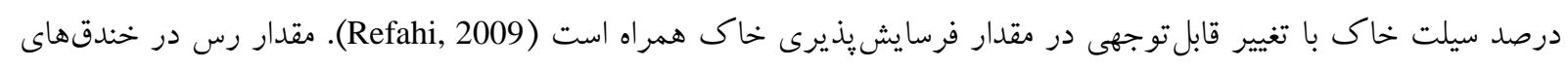

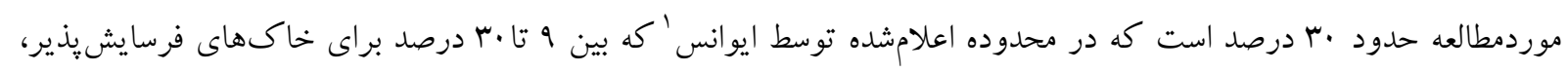

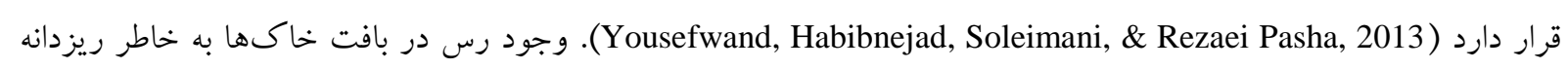

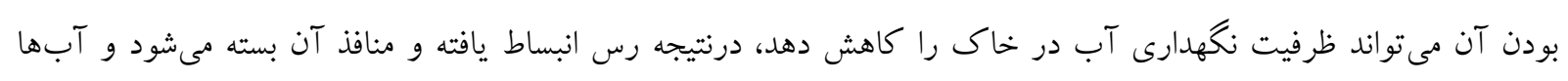

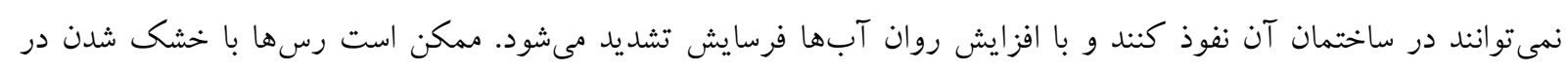

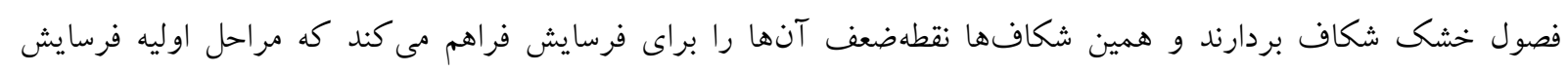

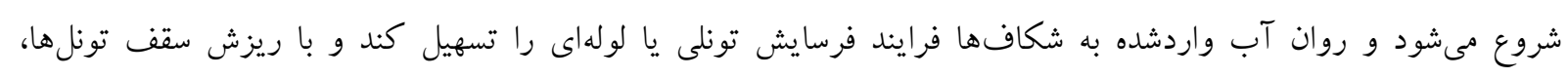




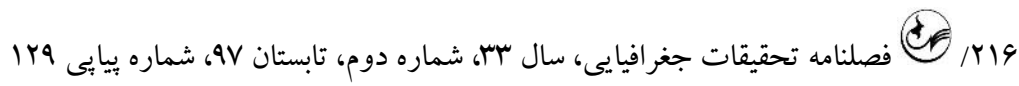
خندقهاى اوليه تشكيل شود. خاكهاى غير جسبناك بيشتر در معرض بيبٍ شدن هستند بنابراين مرحله اوليه تشكيل خندقها

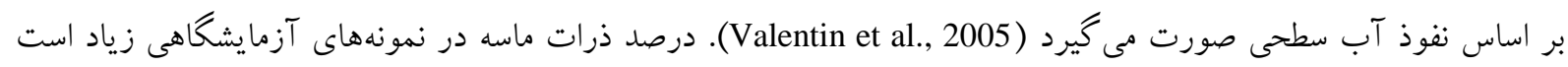

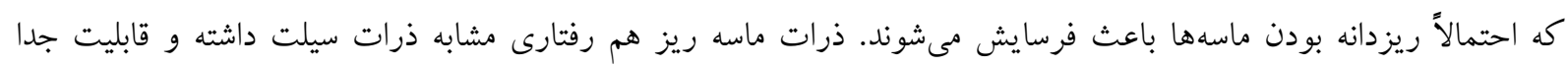

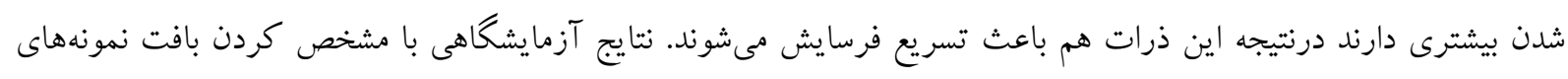

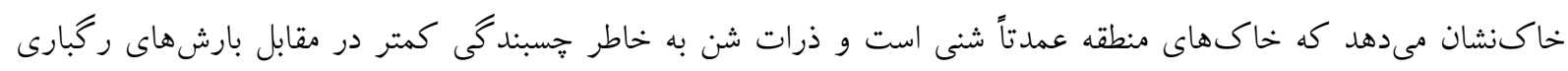

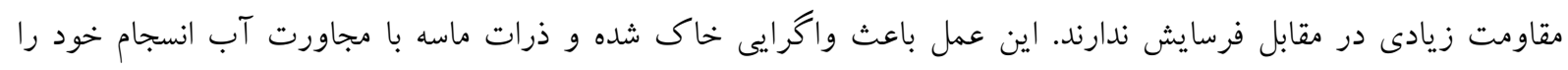

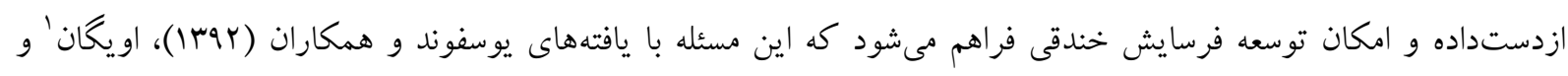

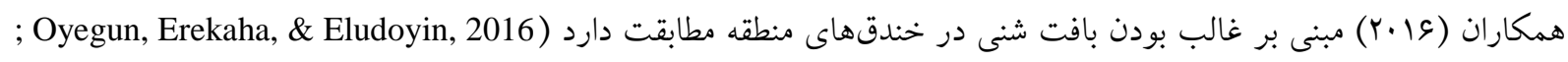

(Yousefwand et al., 2013

جدول ع- ويزگى هاى فيزيكى و شيميايى خاككهاى حوضه شورجاى

\begin{tabular}{|c|c|c|c|c|c|c|}
\hline بافت & درصد شن & درصد سيلت & درصد رس & $\mathrm{EC}(\mu \mathrm{s} / \mathrm{cm})$ & $\mathrm{pH}$ & نمونه \\
\hline شنى، رسى، لومى & $F V / D$ & $r Y / Q$ & $\mu$. & $\Delta V F$ & $N / N$ & 1 \\
\hline شنى، لومى & $F V / \Delta$ & ra & $r V / D$ & $\Delta V I$ & $N / N$ & $r$ \\
\hline شنى، رسى، لومى & $\Delta \Delta$ & 10 & $r$. & $\Delta S q$ & $\Lambda / 11$ & $r$ \\
\hline شنى، رسى، لومى & $\Delta V$ & $\mid r / \Delta$ & $r$. & $\Delta \wedge \mu$ & $N / \cdot r$ & f \\
\hline شنى، رسى، لومى & FV & ro & $T V / \Delta$ & s.1 & $N / \cdot 1$ & $\Delta$ \\
\hline شنى، رسى، لومى & FV & r. & $\mu Y / \Delta$ & DFY & $N / .9$ & $s$ \\
\hline شنى، رسى، لومى & $\Delta$. & $r r / \Delta$ & $T V / \Delta$ & s.. & $N \cdot V$ & v \\
\hline شنى، رسى، لومى & $F V / D$ & ra & $T V / \Delta$ & s11 & $N / \cdot 1$ & $\wedge$ \\
\hline شنى، رسى، لومى & $\Delta V / \Delta$ & 10 & $T V / \Delta$ & $\Delta \Delta$. & $N / \cdot \Delta$ & 9 \\
\hline شنى، رسى، لومى & $\mathrm{FV} / \mathrm{\Delta}$ & r. & $r r / \Delta$ & DYA & $N / r$ & 1. \\
\hline
\end{tabular}

مورفومترى خندقهاى موردمطالعه

بر اساس جدول r بيشتر خندقها در رديف خندقهاى كوجى مىباشند. انواع خندقها بر اساس پارامتر طول به سه دسته

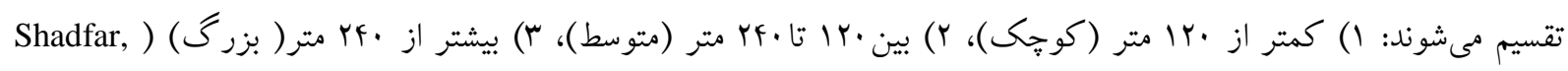

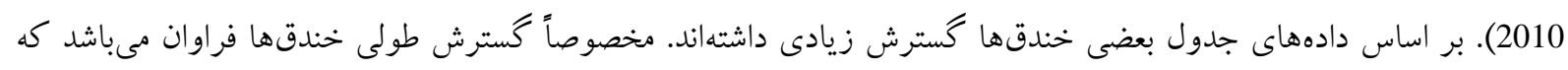

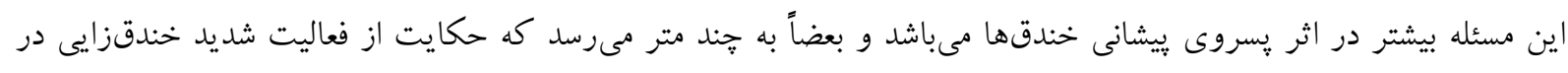

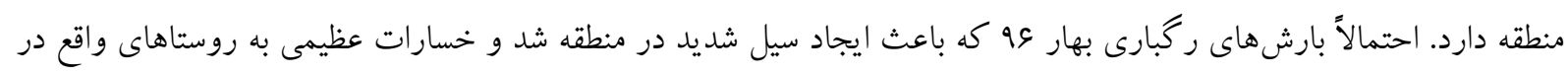
حوضه موردمطالعه تحميل كرد باعث توسعه خندقها كرديده است.

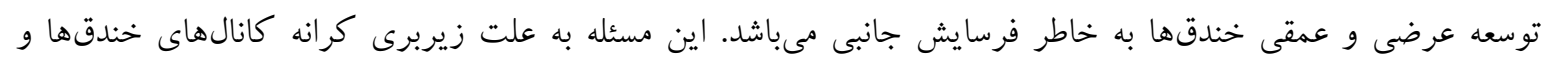

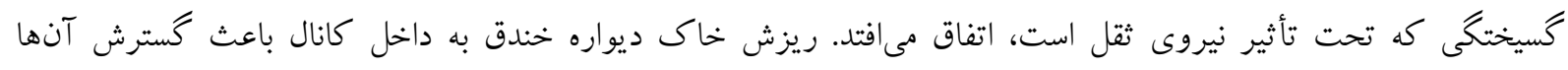

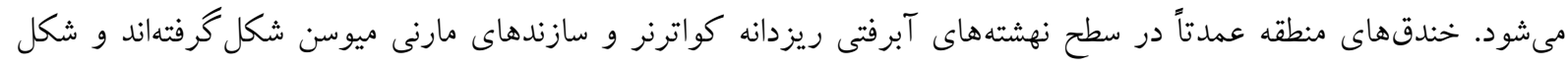

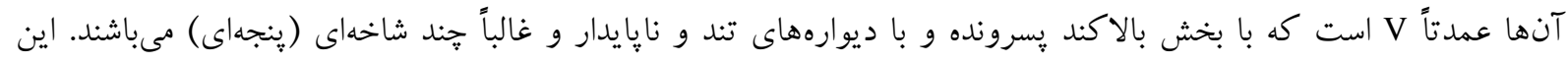


خندقها بهخاطر تراكم زياد رسوبات نرم، در عمق توسعهيافته ولى عرض كمى دارند. تراكم زياد اين نوع خندقها بيشتر در اطراف سد ملاجيق مشاهده مىشوند (شكل F).

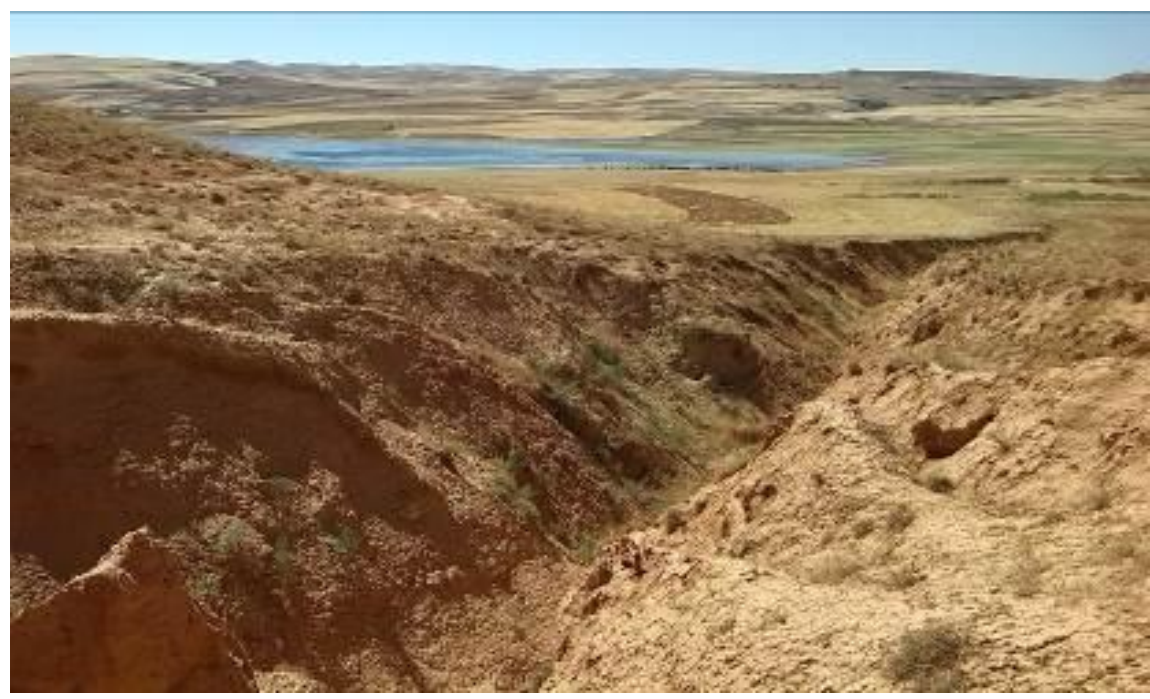

شكلع- نمونهاى از خندقهاى V شكل كه رسوبات آن موجب بر شدن سد ملاجيق مىشود

نوع ديكر خندقها بر روى تراسهاى رودخانهاى ايجادشده و درشيبهاى منتهى به شبكههاى اصلى قرارگرفتهاند.كه از نوع خندقهاى جبههاى مىباشند و با فرسايش قهقرايى حالت يسرونده دارند و باعث تخريب زمينهاى كشاورزى، جادههاى روستايى و كانالهاى آبيارى مىشوند. البته اين مسئله با حضور مستمر آب صورت مى كيرد كه بارشهاى بهارى شديد بهعنوان موتور محر كه خندقزايى عمل مى كند.

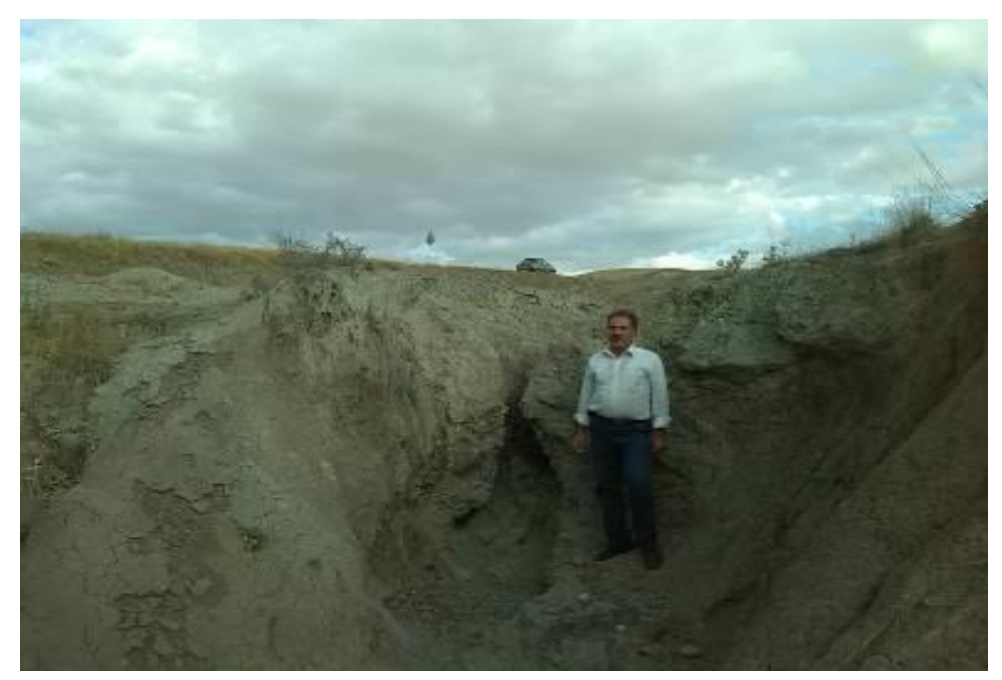

شكل 0- نمونهاى از خندقها كه از قسمت رأس حالت پسروى دارند

يديده ياى يينگ هم در توسعه خندقها نقش مهمى داشته است. ياى يينگ عبارت است از؛ جريان زيرزمينى و زير شويى مواد قابل انفصال و انحلال كه گاهى به آن فرسايش تونلى نيز مى كويند (Ahmadi, 1999). ايجاد راهروهاى زيرزمينى بهصورت حفرههاى واقعى در ديواره خندقها موجب كسترش آنها مىشود. حفرههاى مذكور مراحل اوليه تحول خود را طى مى كنند. كسترش اين راهروهاى زيرزمينى و سֶّ ريزش سقف آنها باعث توسعه خندقها مىشود. اين راهروها عمدتاً بهوسيله رسوبات نفوذيذير، قابليت انحلال و احتمالاً در اثر تمركز جريانهاى سطحى، كه آب را به داخل شكافها هدايت 


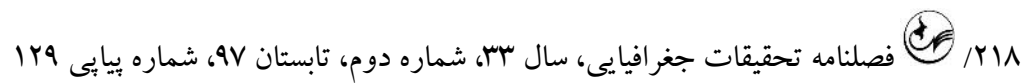
مى كنند ايجاد مىشوند. جريانات زيرسطحى هم به علت ريزدانه بودن سازندها (سيلت، رس) و انحلاليذير (نمك، گج و آهك) باعث فرسايش تونلى مىشوند. در حوضه موردمطالعه در سطح سازندهاى مارنى و سيلت دار در سطوح كم شيب فرسايش توند فئلى عامل مهمى در شكل زايى

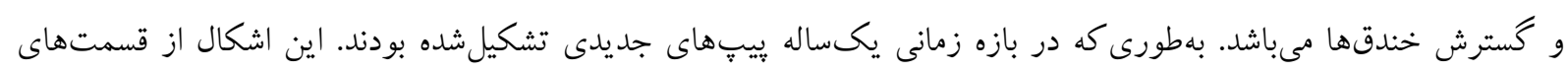

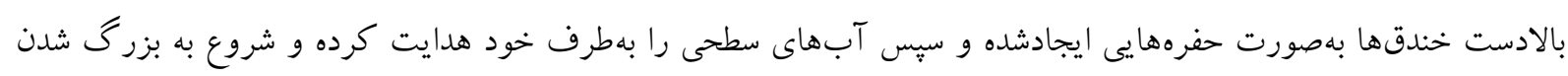

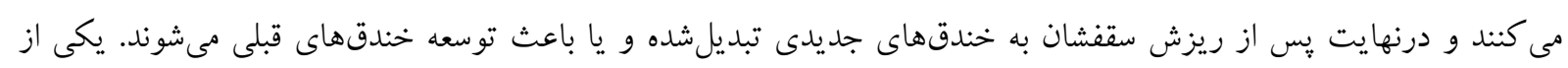

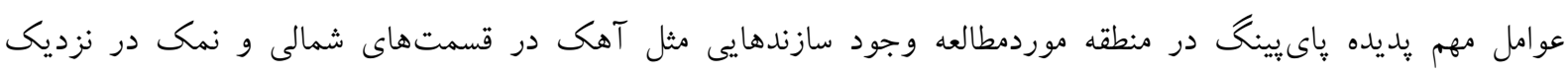

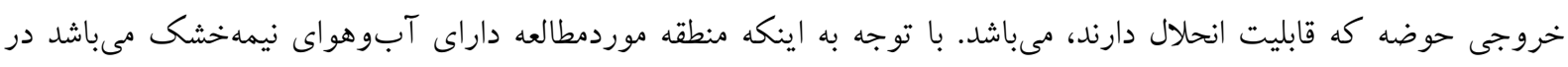

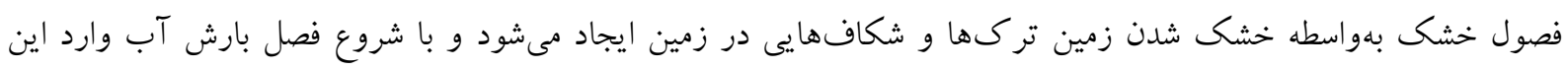

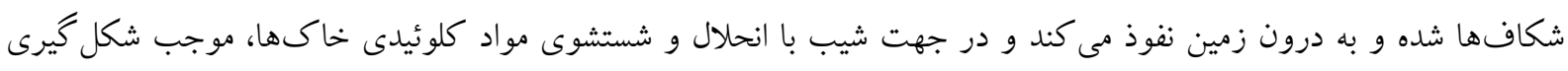

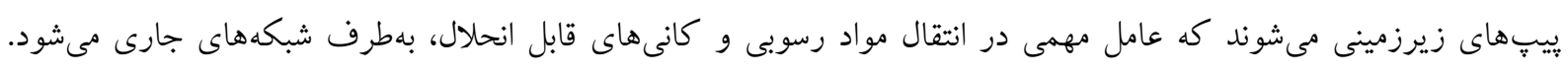

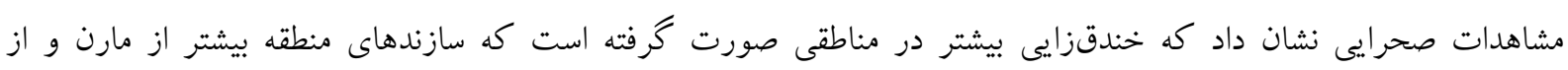

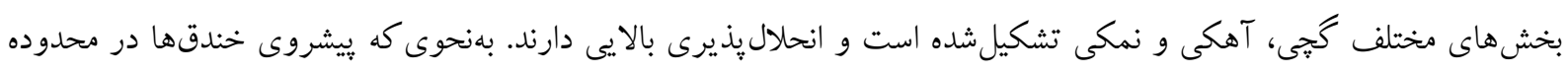

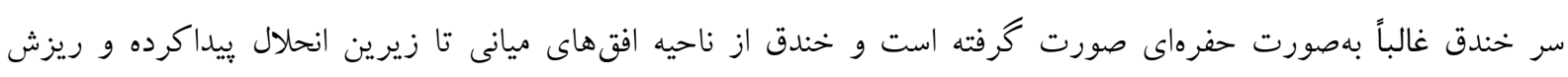

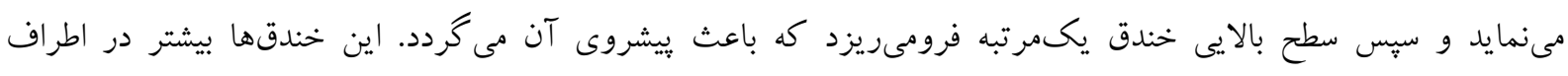
روستاى تكانلوى شهرستان جاراويماق مشاهده مىشوند و در اطراف بستر رودخانه توسعه يافتهاند (شكل هاى ع و و V).

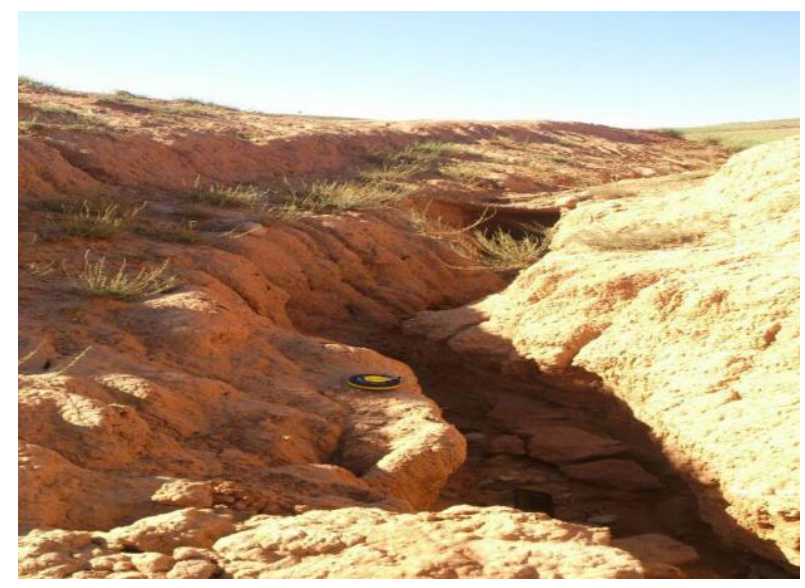

شكل Y- نمونهاى از خندقها در اثر فروريختن سقف تونل

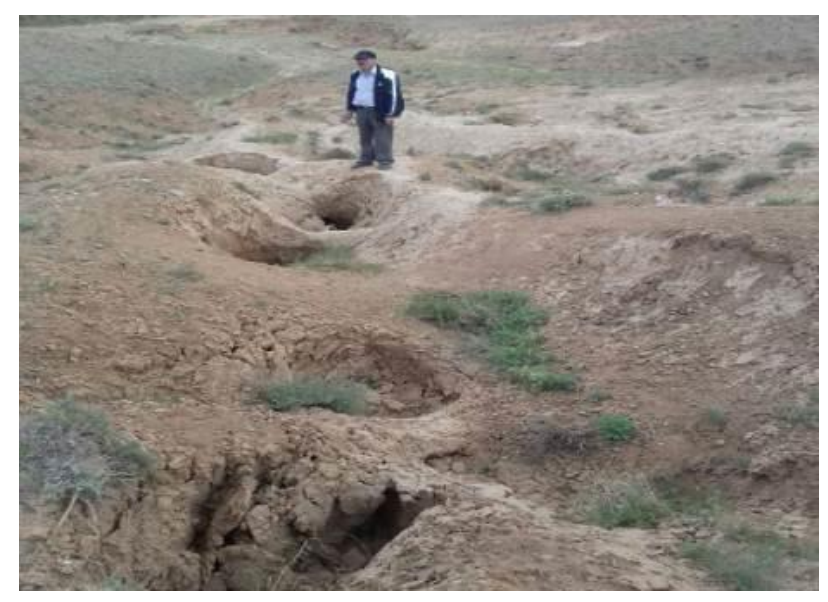

شكل 1-آغاز فرسايش تونلى در حوضه شورجاى 
بر بـى و تجزيه و تحليل عوامل موثر بر ايجاد و توسعه فرسايش خندقى ... /

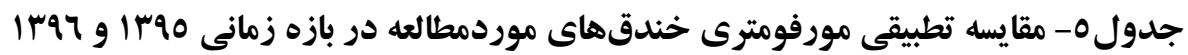

\begin{tabular}{|c|c|c|c|c|c|c|c|c|}
\hline 1790 & عرض & عمق & طول & 1 1r9s & عرض & عمق & طول & نوع خندق \\
\hline 1 & $1 / 0$ & $1 / \Lambda$ & rq & 1 & $1 / \Delta \Delta$ & I/As & $\mu$. & كوجָ \\
\hline r & $1 / r$ & s/ & qf & r & $1 / \mu$ & $\cdot / 1$ & 91 & كوجָ \\
\hline$r$ & $f / s$ & $r / r$ & 10 & $r$ & $\Delta$ & $r / \mu$ & IV & كوجָ \\
\hline f & $r / V$ & $1 / 9$ & rA & f & $\Gamma / \Lambda$ & r & $r q / \Delta$ & كوجى \\
\hline a & $9 / 1$ & $r / V$ & MF & $\Delta$ & $9 / \mu$ & $r / \Lambda$ & $r F / Y$ & كوجى \\
\hline$\varepsilon$ & $\Delta / \Lambda$ & $1 / V$ & Mr & $\varepsilon$ & $\varepsilon$ & $1 / V a$ & rT & كوجى \\
\hline v & s/s & $r / f$ & vi & v & $s / \Lambda$ & $r / s$ & $V Y / \Delta$ & كوجى \\
\hline$\Lambda$ & $V / I$ & $r / r$ & 1.8 & $\wedge$ & $V / r$ & $F / D$ & $1 \cdot V$ & كوجى \\
\hline 9 & $\Delta$ & r & 9. & 9 & Q & $\mu / \Lambda$ & $9 r$ & كوجى \\
\hline 1. & $r / V$ & .190 & lar & 1. & $r / q$ & $\cdot / 91$ & $1 \Delta \Delta$ & متوسط \\
\hline 11 & $\Lambda / \Delta$ & $1 / 9$ & $\Delta r$ & 11 & $\Lambda / \Lambda$ & $r / l$ & $\Lambda r$ & كوجָ \\
\hline Ir & $r / f$ & $r / l$ & st & Ir & $r / s$ & $r / r$ & r & كوجָ \\
\hline ir & $V / I$ & $r / f$ & rq & 14 & $V / \mu$ & $r / s$ & a. & كوجָ \\
\hline if & 9 & $0 / 9$ & TIS & if & $9 / 8$ & $s / r$ & MM & متوسط \\
\hline 10 & 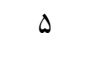 & $r / l$ & 19. & 10 & $\Delta / f$ & $r / r$ & 194 & متوسط \\
\hline 18 & $\varepsilon$ & r & 10 & is & $\varepsilon / f$ & $r / r$ & lar & متوسط \\
\hline IV & 11 & $\Delta$ & rr. & IV & $11 / 0$ & $\Delta / f$ & rta & متوسط \\
\hline 11 & $r / G$ & $r / r$ & rA & 11 & $Y / V$ & $r / r$ & $r$. & كوجى \\
\hline 19 & $r / V$ & $r / r$ & a. & 19 & $r / \Lambda$ & $r / r$ & $\Delta r$ & كوجָ \\
\hline$r$. & $1 \cdot / f$ & s & v. & $r$. & $1 \cdot / V$ & $s / r$ & $v r$ & كوجى \\
\hline MI & $\mu / V$ & $r / F$ & $1 \wedge \Delta$ & YI & $r / q$ & $r / Q$ & $1 M$ & متوسط \\
\hline rY & $\cdot / V$ & $\cdot / 8$ & r. & rY & $\cdot / 1$ & $\cdot / V$ & re & كوجى \\
\hline r & $1 / 4$ & $1 / f$ & Fa & r & $1 / 0$ & $1 / 0$ & FV & كوجֶ \\
\hline YF & $s / \mu$ & $r / r$ & $1 . r$ & rF & $s / 0$ & $r / r$ & $1 \cdot 0$ & كوجָ \\
\hline ra & $1 / 0$ & $1 / r$ & 10. & ra & $1 / V$ & $1 / 0$ & $10 \Delta$ & متوسط \\
\hline re & 1 & $\cdot / 8$ & r & re & $1 / 1$ & $\cdot / V$ & f. & كوجى \\
\hline
\end{tabular}

نتيجل گيرى

بررسى و تجزيه تحليل نتايج مربوط به شكل گيرى و گسترش فرسايش خندقى در حوضه موردمطالعه در رابطه با سـازندهاى

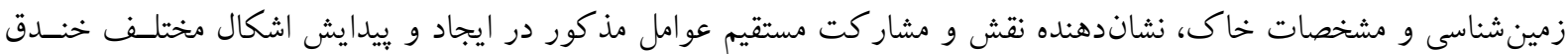

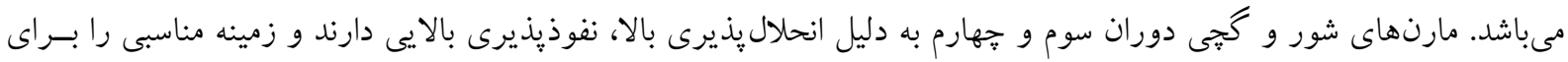

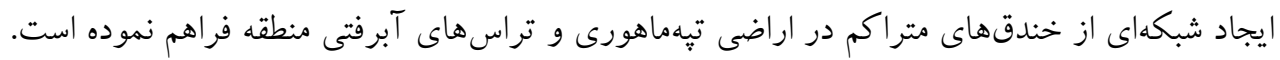

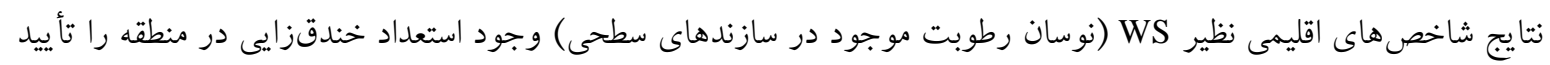

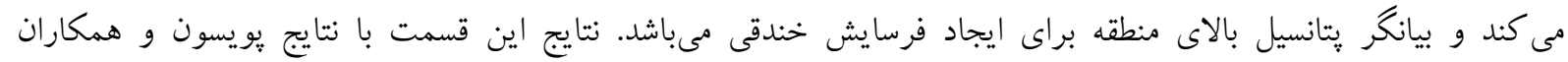




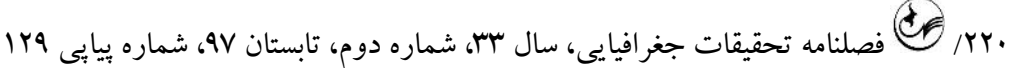

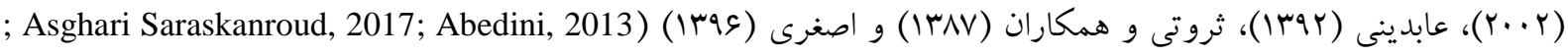
Soesen et al., 2002; Servati et al., 2008

با مشخص كردن بافت نمونهاى سطحى و عمقى خاك با استفاده از درصد ذرات مشاهده گرديد كه خاكىهاى منطقه

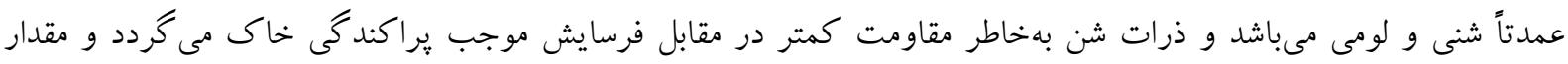

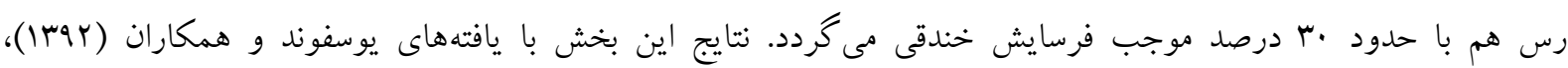

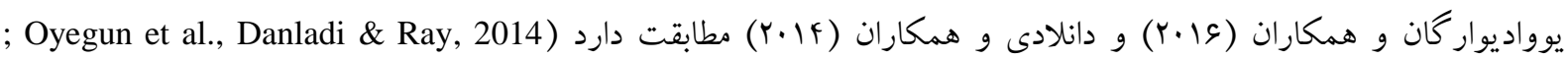

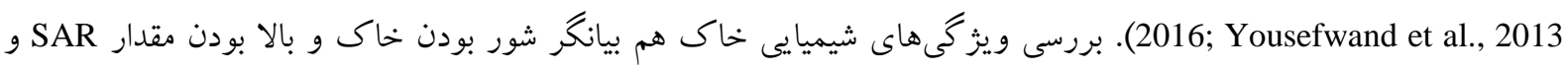

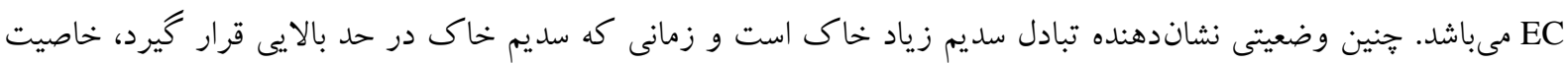

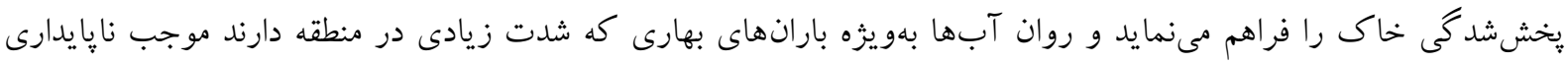

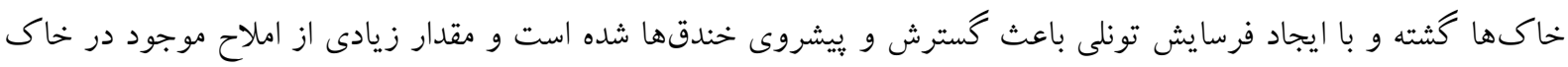

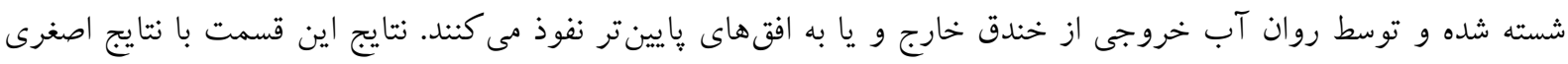

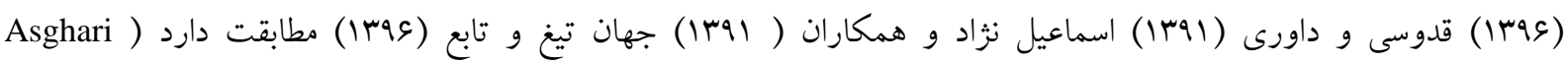

.(; Ghodousi \& Davari-Rad, 2012; Ismail-Nejad et al., 2012; Jahanatigh \& Tabeh, 2017Saraskanroud, 2017 نتايج مورفومترى خندقهاى منطقه هم بيانگر رشد سريع خندقها است. مشاهدات ميدانى نشان داد كه رشد سريع خندقها در

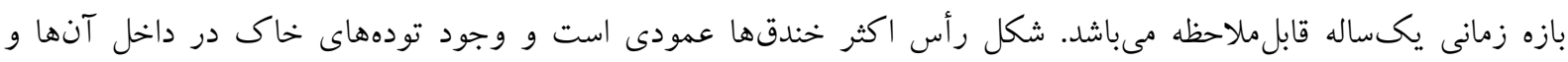

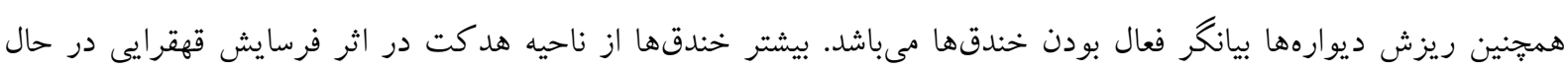

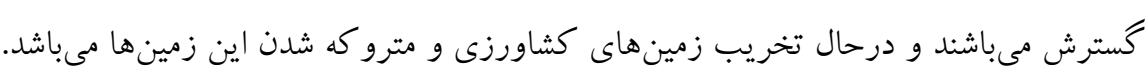

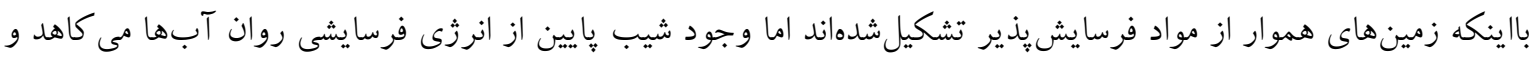

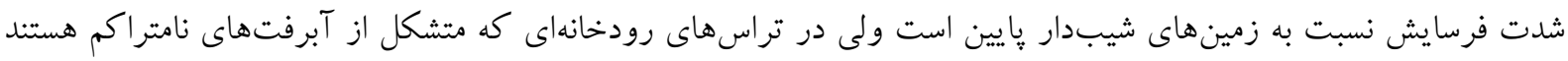

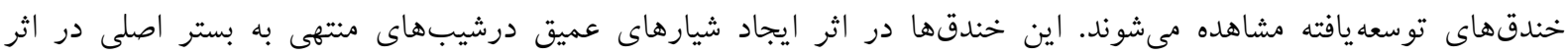

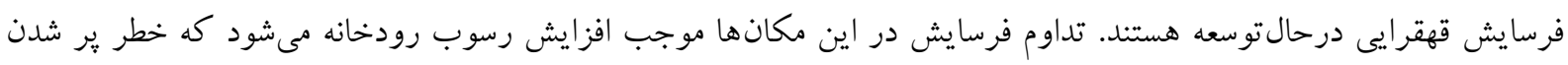

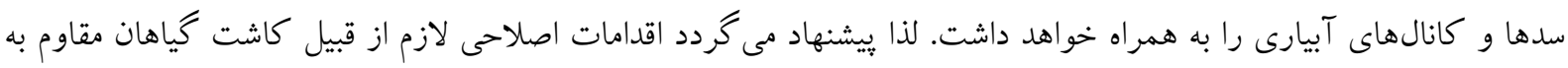

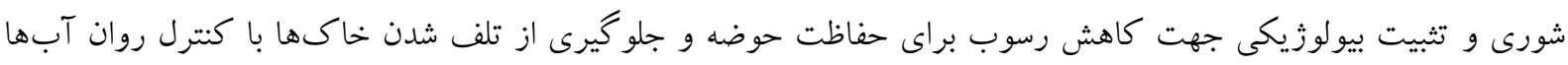
صورت كيرد.

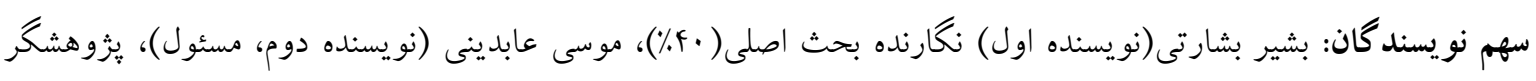

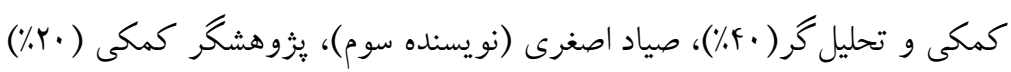

\section{منابع و مآخذ}

Abedini, M. (2009). Quantity study on hydrogeomorphological issues of Lykwan Chai river with emphasis on soil and sediment srosion (southeast of Ardebil). Geography and Development Journal, 7(15), 71- 88. (Persian)

Abedini, M. (2013). Quantitative analysis of gully erosion in Kalghan-Chaj basin (east of Sahand). Geography and Urban Area Journal, 3(7), 97- 110. (Persian)

Ahmadi, H. (1999). Applied geomorphology (water erosion) (Vol. 1). Tehran: Tehran University. (Persian)

Asghari Saraskanroud, S. (2017). Analysis of affecting factors on creating gully in the eastern shores of Urmia Lake. Geographical Space Journal, 17(58), 285-301. (Persian) 
Bayati Khatibi, M., Rajabi, M., \& Karami, F. (2011). Study of topographic thresholds and analysis of the role of type of surface formation in the development of gullies in the mountains of semi-aride areas (case Study: Shoorchai basion. Journal of Geography and Environmentale Planning, 22(1), 15-34. (Persian)

Conoscenti, C., Angileri, S., Cappadonia, C., Rotigliano, E., Agnesi, V., \& Märker, M. (2014). Gully erosion susceptibility assessment by means of GIS-based logistic regression: a case of Sicily (Italy). Geomorphology, 204, 399-411 . [DOI:10.1016/j.geomorph.2013.08.021]

Danladi, A., \& Ray, H. H. (2014). An analysis of some soil properties along gully erosion sites under different land use areas of Gombe Metropolis, Gombe State, Nigeria. Journal of Geography and Regional Planning, 7(5), 86-96.[DOI:10.5897/JGRP2014.0438]

Deng, Q., Miao, F., Zhang, B., Luo, M., Liu, H., Liu, X., . . Liu, G. (2015). Planar morphology and controlling factors of the gullies in the Yuanmou Dry-hot valley based on field investigation. Journal of Arid Land, 7(6), 778-793 .[DOI:10.1007/s40333-015-0135-8]

Ehiz, O. S., \& Omougbo, U. N. (2013). Evaluating factors responsible for gully development at the University of Benin .Journal of Emerging Trends in Engineering and Applied Sciences (JETEAS), 4(5), 707-713 .

Feizenya, S., Heshmati, M., Ahmadi, H., \& Ghodousi, J. (2007). The study of the gully erosion of the Aghajari marlian formation in Qasr-Shirin area. Journal of Research and Development in Natural Resources, 20(1), 32- 40. (Persian)

Ghodousi, J., \& Davari-Rad, A. (2012). The Effect of physical and chemical properties of soil in gully erosion evente and morphology of gullies, Collection of the 2 nd Tehran erosion and sedimentation conference. (Persian)

Ismail-Nejad, L., Sayed-Mohammadi, J., \& Bakhshipour, R. (2012). The effect of physical, chemical and soil physiogical properties on the morphology of gullies in marlian lands of south of Guilan. Researches in Watershed Journal, 25(4), 7-16. (Persian)

Jahanatigh, M., \& Tabeh, M. (2017). Comparing soil physico-chemical characteristics and trapezoidal and vshaped gully morphology with different land uses in dry areas, case study: Hossinzahi and Nalint regions of Chabahar. Journal of Engineering and Watershed Management, 9(3), 308-317. (Persian)

Kardel, F., \& Tajari, A. (2015). Influence of gully erosion on soil moisture of abandoned farming dry land and rangeland in loess land (Case study: Kale-Shour watershed, Golestan province). Electronic Journal Soil Managment and Sustainable Production, 5(2), 181-195. (Persian)

Khoojeh, N., Ghodousi, J., \& Esmaeili, R. (2012). Investigation of the relation of soil physiochemical characteristics and initiation and expansion of gully erosion in Temer Ghareh Ghozi watershed, Golestan province. Journal of Watershed Management Research, 3(5), 27-41. (Persian)

Mallam, I., Iguisi, E. O., \& Tasiu, Y. U. (2016). An assessment of gully erosion in kano metropolis, Nigeria. Agricultural Science, 5(1), 14-27 .

Mohammad Ebrahimi, M. R., \& Vafakhah, M. (2015). Investigation of the role of soil and non-soil parameters in development of linear gully erosion in Agh Emam watershed. Soil Researches Journal, 29(4), 487-498 . (Persian)

Nohehgar ,A., \& Heidarzadeh, M. (2011). Study of physico-chemical and morphometric properties of gully areas (case study: Gazir, Hormozgan). Environmental Erosion Researches Journal, 1(1), 29-43. (Persian)

Oparaku, L. A., \& Iwar, R. T. (2018). Relationships between average gully depths and widths on geological sediments underlying the Idah-Ankpa Plateau of the North Central Nigeria. International Soil and Water Conservation Research, 6(1), 43-50 .[DOI:10.1016/j.iswcr.2017.12.003]

Oyegun, C. U., Erekaha, U., \& Eludoyin, O. S. (2016). Gully characterization and soil properties in selected communities in Ideato South Lga, Imo State, Nigeria. Nature and Science, 14(2), 78-86 .

Poesen, J., Vanderkerckhove, L., Nachtergaele, J., Oostwoud Wijdenes, D., Verstraeten, G., \& Wesemael, B. (2002). Gully Erosion in Dryland Environments. Dryland Rivers: Hydrology and Geomorphology of Semi-Arid. Channels. 229-262.

Refahi, H. (2009). Water erosion and its control (Six ed.). Tehran: Tehran University Press. (Persian)

Rienks, S. M., Botha, G. A., \& Hughes, J. C. (2000). Some physical and chemical properties of sediments exposed in a gully (donga) in northern KwaZulu-Natal, South Africa and their relationship to the erodibility of the colluvial layers. CATENA, 39(1), 11-31. [DOI:10.1016/S0341-8162(99)00082-X]

Servati, M. R., Ghodousi, J., \& Dadkhah, M. (2008). Effective factors in the formation and expansion of gully erosion in loss. Research and Formation in Natural Resources, 21(1), 20- 33. (Persian)

Shadfar, S. (2010). Introduction to gully erosion (First ed.). Tehran: Entekhab Publication. (Persian)

Shahrivar, A., Boon Sung, C., Jessop, S., Rahim, A., \& Sufi, M. (2012). Roles of SAR and EC in gully erosion development (a case study of Kohgiluyeh and Boyer-Ahmad province, Iran) Journal of Research in Agricultural Science, 8(1), 1-12

Shit, P. K., Bhunia, G .S., \& Maiti, R. (2013). Assessment of factors affecting ephemeral gully development in badland topography: A case study at garbheta badland (Pashchim Medinipur). International Journal of Geosciences, 4(2), 461-470. [DOI:10.4236/ijg.2013.42043] 


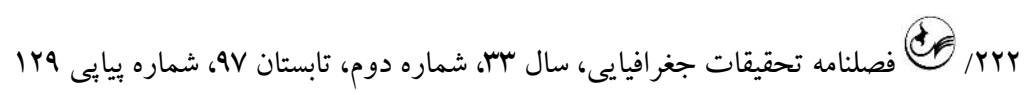

Tebebu, T., Abiy, A., Zegeye, A., Dahlke, H., Easton, Z., Tilahun, S., . . . Dadgari, F. (2010). Surface and subsurface flow effect on permanent gully formation and upland erosion near Lake Tana in the northern highlands of Ethiopia. Hydrology and Earth System Sciences, 14(11), 2207-2217. [DOI:10.5194/hess14-2207-2010]

Valentin, C., Poesen, J., \& Li, Y. (2005). Gully erosion: Impacts, factors and control. CATENA, 63(2), 132-153 . [DOI:10.1016/j.catena.2005.06.001]

Yousefwand, S., Habibnejad, M., Soleimani, K., \& Rezaei Pasha, M. (2013). Lithological and geological impacts on gully erosion (case study: Seif Abad watershed, Lorestan). Water and Soil Science, 17(65), 139-151. (Persian) 